\title{
Application of Reverse Genetics in Functional Genomics of Potyvirus
}

\author{
Maathavi Kannan ${ }^{1}$, Zamri Zainal ${ }^{1,2}$, Ismanizan Ismail ${ }^{1,2}$, Syarul Nataqain Baharum ${ }^{1}$ (]) \\ and Hamidun Bunawan 1,*(D) \\ 1 Institute of Systems Biology, Universiti Kebangsaan Malaysia, Bangi 43600, Malaysia; \\ maathavikannan95@gmail.com (M.K.); zz@ukm.edu.my (Z.Z.); maniz@ukm.edu.my (I.I.); \\ nataqain@ukm.edu.my (S.N.B.) \\ 2 Department of Biological Sciences and Biotechnology, Faculty of Science and Technology, \\ University Kebangsaan Malaysia, Bangi 43600, Malaysia \\ * Correspondence: hamidun.bunawan@ukm.edu.my; Tel.: +60-3-8921-4554
}

Received: 22 June 2020; Accepted: 14 July 2020; Published: 26 July 2020

\begin{abstract}
Numerous potyvirus studies, including virus biology, transmission, viral protein function, as well as virus-host interaction, have greatly benefited from the utilization of reverse genetic techniques. Reverse genetics of RNA viruses refers to the manipulation of viral genomes, transfection of the modified cDNAs into cells, and the production of live infectious progenies, either wild-type or mutated. Reverse genetic technology provides an opportunity of developing potyviruses into vectors for improving agronomic traits in plants, as a reporter system for tracking virus infection in hosts or a production system for target proteins. Therefore, this review provides an overview on the breakthroughs achieved in potyvirus research through the implementation of reverse genetic systems.
\end{abstract}

Keywords: potyvirus; reverse genetics; virus biology; transmission; viral protein; virus-host interaction; viral vector

\section{Introduction}

Reverse genetics of RNA viruses refers to the generation of recombinant viruses through site-directed mutagenesis such as substitution, deletion or insertion [1]. This consequently made various phenotypic studies possible, apart from providing a powerful tool to enhance our knowledge on life cycles and pathogenic mechanisms of RNA viruses as well as the structure or function of individual viral genes [2,3]. Besides that, reverse genetics approaches have largely contributed to the development of antiviral therapeutics, vaccines [4,5], and vectors [6]. The first success in reverse genetics for an RNA virus was reported for poliovirus, a positive-stranded RNA virus in 1981 [7]. Since then, reverse genetics technology has greatly revolutionized the studies on almost every group of positive-strand viruses including potyviruses [8].

Potyvirus is a genus of virus that belongs to the family Potyviridae. Potyviruses are among the most economically important and widely spread groups of plant viruses [9]. The genus comprises 158 species including Potato virus $Y$ as the type species [10]. The picornavirus-like supergroup [11] is transmitted non-persistently by aphids. However, some potyviruses are also transmitted through seeds [12]. Potyviruses have a single-stranded RNA genome of around $10 \mathrm{~kb}$, with a $3^{\prime}$ terminal poly(A) tail and a VPg protein at its $5^{\prime}$ end [13]. The members of potyvirus group exist as flexuous rods ranging from 720 to $900 \mathrm{~nm}$ in length [14]. The single open reading frame (ORF) in the RNA molecule is translated into a large polyprotein. Proteolytic cleavage of the polyprotein by three viral proteinases [15,16] gives rise to ten functional proteins as follows: P1, HC-Pro, P3, 6K1, CI, 6K2, VPg, 
NIa-Pro, NIb, and CP $[17,18]$. Additionally, the expression of a P3N-PIPO protein has been recently exhibited as a result of either a transcriptional slippage or ribosomal frameshift $[19,20]$.

Infectious clone technology represents the most commonly applied reverse genetics system. Cloning of an infectious clone was first described for Brome mosaic virus [21]. Since then, infectious clones for many other plant RNA viruses were successfully obtained as either in vivo or in vitro trancripts. For in vitro strategy, the viral cDNAs are cloned under bacteriophage promoters such as T7, T3, or Sp6 followed by the generation of in vitro transcripts [22,23]. On the other hand, in vivo infectious transcripts are driven by Cauliflower mosaic virus $35 \mathrm{~S}$ promoter in a binary vector. Cells transformed with the plasmids containing virus cDNA clones are then introduced into plants through agroinfiltration, particle bombardment, or rubbing onto the leaf's surface [24,25]. In this review, we describe and summarise the application of reverse genetics in potyviral studies based on the potyvirus infectious clones developed to date.

\section{Applications/Impacts}

\subsection{Point Mutation}

Point mutation refers to a change occurred within a gene due to a single base pair alteration in the DNA sequence. During translation, conversion of RNA copied from the DNA into a sequence of amino acids would take place and point mutations usually cause a variety of effects on the protein synthesized at the final stage [26].

\subsubsection{Effect of Point Mutation on Virus Biological Properties}

Mutagenesis studies aimed to characterize the phenotypic consequences resulting from genome modification, based on how the progenies differ from their respective wild type [27]. To date, various site-specific mutations in the potyviral genomes and screening of the progeny viruses have been conducted (Table 1). For instance, a 10-fold reduction in virus accumulation could be observed when a single point substitution, serine to glycine at position 7 was introduced in the DAS motif of $C P$ $\mathrm{N}$ terminus of B11 isolate of Potato virus A (PVA). However, aphid transmissibility of the virus was still retained [28]. Further information on potyviral noncoding region (NCR) roles were gathered by studying the changes observed in biological characteristics of mutants with manipulated NCR. In line with that, Clover yellow vein virus, $\mathrm{pCIYVV} \mathrm{cDNA} \mathrm{clones} \mathrm{containing} \mathrm{no} \mathrm{poly(A),} \mathrm{poly(A)} \mathrm{with}$ shorter A residues, or various oligonucleotide sequences downstream were constructed. All RNA progenies obtained from the pCIYVV cDNA constructs had poly(A) tails with infectivity varies along the sequences introduced. This suggested the addition of poly(A) to be independent of template, yet essential to maintain the infectivity of potyviral cDNA [29]. Besides that, a deletion mutation introduced in the NCR at $5^{\prime}$ end of Plum pox virus (PPV) revealed that the region between nucleotides 39 and 145 contributes to competitive fitness of the viral population [30]. A point mutation engineered into Turnip mosaic virus, TuMV-pXBS7/TuMV-pXBS8 chimeric viruses have allowed the mapping of a symptom severity determinant in the $3^{\prime}$-terminal UTR of pXBS8-derived virus [31]. 
Table 1. Applications of reverse genetics techniques on biological properties related studies of potyviruses.

\begin{tabular}{|c|c|c|c|}
\hline Virus & Genome Manipulation & Findings & Reference \\
\hline $\begin{array}{l}\text { Tobacco vein mottling virus } \\
\text { TVMV-WT }\end{array}$ & $\begin{array}{l}\text { Amino acid substitution of } \mathrm{Lys}_{307} \rightarrow \mathrm{Glu}_{307} \\
\text { Thr-Ser } 283 / 284 \rightarrow \text { Ile-Asp } 283 / 284 \text { and } \\
\text { Thr-Ala }_{368 / 369} \rightarrow \text { Leu-Glu } 368 / 369 \text { in HC-Pro }\end{array}$ & $\begin{array}{l}\text { TuMV-307, TuMV-283/284 and TuMV-368/369 mutants-infected } \\
\text { plants had no symptoms (11-30 day after inoculation) and } \\
\text { showed reduced virus accumulation (Week 1-4). }\end{array}$ & [32] \\
\hline Tobacco etch virus TEV & $\begin{array}{l}\text { pTEV7D-GUS contains site-directed mutagenesis in } \\
\text { GUS-HC-Pro fusion protein: } \\
\text { - } \quad \text { TEV-2del retained nucleotides } \text { GUS }_{1} \rightarrow \mathrm{GUS}_{135} \text { but } \\
\text { lost HC-Pro sequence up to nucleotide } 207 \\
\text { - } \quad \text { TEV-7del } \mathrm{l}_{\mathrm{r}} \text { retained nucleotides } \mathrm{GUS}_{1} \rightarrow \mathrm{GUS}_{9} \text { but } \\
\text { lost HC-Pro sequence up to nucleotide } 265\end{array}$ & $\begin{array}{l}\text { The sequence deleted from TEV-2del }{ }_{\mathrm{r}} \text { and TEV-7del } \text { composed }_{\mathrm{r}} \\
\text { the N-terminal domain and a cysteine-rich motif of HC-Pro. The } \\
\text { ability of these mutants to replicate and move systemically } \\
\text { indicated that the N-terminal domain of HC-Pro is not a factor } \\
\text { essential for these processes. Although both TEV-2del }{ }_{\mathrm{r}} \text { and } \\
\text { TEV-7del } \mathrm{r}_{\mathrm{r}} \text { were viable in plants, a negative effect on accumulation } \\
\text { of viral RNA and coat protein could be observed, suggesting a } \\
\text { potential function of HC-Pro in enhancing viral replication. }\end{array}$ & {$[11]$} \\
\hline \multirow[t]{2}{*}{$\begin{array}{l}\text { Plum pox virus } \\
\text { PPV-D }\end{array}$} & $\begin{array}{l}\text { PPV mutant that lacked long sequences located between } \\
\text { nucleotides } 39 \text { and } 145 \text { in } 5^{\prime} \text { NCR (146 nt long) }\end{array}$ & $\begin{array}{l}\text { The deleted region is not necessary for genomic RNA replication, } \\
\text { but contribute to the competitive fitness of the PPV since the } \\
\text { mutants were not able to compete with the wild-type strain in } \\
\text { co-inoculation experiments. }\end{array}$ & [30] \\
\hline & $\begin{array}{l}\text { PPV mutant without sequences between nucleotides } 127 \\
\text { and } 145 \text { in } 5^{\prime} \text { NCR }\end{array}$ & $\begin{array}{l}\text { Plant infected with PPV mutant viruses } \Delta[127,145] \text { showed a } \\
\text { very mild symptoms. However, the wild-type symptom severity } \\
\text { was recovered after spontaneous second-site mutations. }\end{array}$ & \\
\hline \multirow[t]{3}{*}{$\begin{array}{l}\text { Clover yellow vein virus } \\
\text { CIYVV }\end{array}$} & $\begin{array}{l}\text { Mutations in poly(A) (10 A residues) of pClYVV: } \\
\text { pClYVV-PA5: Shorter by } 5 \text { (A) } \\
\text { pClYVV } \triangle \text { PA: Poly(A)-deficient }\end{array}$ & $\begin{array}{l}\text { Mutants still infectious, but the infectivity was reduced } \\
\text { compared to that of pCIYVV }\end{array}$ & [29] \\
\hline & $\begin{array}{l}\text { pCIYVV PAmut series (pClYVV PAmut } 1,2,3,4 \text { ) consisted } \\
\text { of plasmids with T residues in the poly }(\mathrm{A}) \text { tract }\end{array}$ & $\begin{array}{l}\text { Mutants with more than five continuous A residues (pCIYVV } \\
\text { PA5,-PAmut 2, and -PAmut } 3 \text { ) are more infectious than those } \\
\text { having zero to two A residues (pClYVV } \triangle \mathrm{PA} \text {, -PAmut 1, and } \\
\text {-PAmut } 4 \text { ). Hence, minimum 5-10 } \\
\text { infectivity. }\end{array}$ & \\
\hline & $\begin{array}{l}\text { pClYVV 3'dup 1: Last } 5 \text { nts, CGAGA was duplicated } \\
\text { pClYVV 3'dup 4: Last } 10 \text { nts, TAGAGCGAGA was } \\
\text { duplicated }\end{array}$ & $\begin{array}{l}\text { The infectivity of pCIYVV } 3^{\prime} \text { dup } 4 \text { was higher than that of } \\
\text { pClYVV } 3^{\prime} \text { dup } 1 \text {. This suggested that the length of duplicated } \\
\text { sequence (downstream of the poly(A) site) might have enhanced } \\
\text { mutants' infectivity. }\end{array}$ & \\
\hline
\end{tabular}


Table 1. Cont

\begin{tabular}{|c|c|c|c|}
\hline Virus & Genome Manipulation & Findings & Reference \\
\hline $\begin{array}{l}\text { Clover yellow vein virus } \\
\text { CIYVV }\end{array}$ & $\begin{array}{l}\text { - A series of pClYVVdel mutants with a deletion of } \\
\text { various parts in } 3^{\prime} \mathrm{NCR} \\
\text { - A series ofpClYVV plasmids containing duplicated } 3^{\prime} \\
\text { terminal region }\end{array}$ & $\begin{array}{l}\text { All deletion mutants lacking any portion in } 3^{\prime} \mathrm{NCR} \text { were not } \\
\text { infectious. Various mutants with duplicated } 3^{\prime} \text { terminal sequences } \\
\text { were infectious only when the authentic } 3^{\prime} \text { terminal sequence was } \\
\text { restored, probably by recombination, and none of the constructs } \\
\text { retained the original sequence in progeny viral RNA. The } \\
3^{\prime} \text {-terminal region of ClYVV contains cis-acting elements that are } \\
\text { strictly necessary for ClYVV replication. }\end{array}$ & {$[33]$} \\
\hline $\begin{array}{l}\text { Potato virus A } \\
\text { PVA-B11 \& }\end{array}$ & $\begin{array}{l}\text { Replacement of the entire CP gene of PVA-B11 with the CP } \\
\left.\text { gene of PVA-U (B11- } U_{C P}\right)\end{array}$ & $\begin{array}{l}\text { Virus accumulation in tobacco reduced 5-fold, to the level of } \\
\text { PVA-U. }\end{array}$ & [28] \\
\hline \multirow[t]{3}{*}{ PVA-U } & $\begin{array}{l}\text { Four simultaneous amino acid substitutions (E88K, H89Y, } \\
\text { G153S and A330T) made in PVA-B11 HC-Pro (according to } \\
\text { PVA-U HC-Pro) }\end{array}$ & $\begin{array}{l}\text { Virus accumulation in tobacco increased 2- to } 4 \text {-fold, to the level of } \\
\text { PVA-B11. }\end{array}$ & \\
\hline & $\begin{array}{l}\text { Simultaneous mutation of HC-Pro and replacement of CP } \\
\text { in PVA-B11 }\end{array}$ & $\begin{array}{l}\text { Delayed systemic movement in tobacco and limited cell-to-cell } \\
\text { movement in potato. }\end{array}$ & \\
\hline & Amino acid substitution of $S_{7} \rightarrow G_{7}$ in CP of PVA-B11 & $\begin{array}{l}\text { The PVA-B11 CP contains a DAS motif (aa } 5-7 \text { ) and is not } \\
\text { aphid-transmissible whereas PVA-U contains a DAG motif and is } \\
\text { aphid-transmissible. S7G mutation restored aphid transmissibility } \\
\text { of PVA-B11. }\end{array}$ & \\
\hline Potato virus A PVA-B11 & $\begin{array}{l}\text { PVA containing: } \\
\text { - GFP inserted at the junction of the NIb and CP } \\
\text { (35S-PVA-GFPNIb/CP) } \\
\text { - All three potential CK2 phosphorylation sites in CP } \\
\text { (Thr-242, Thr-243, and Ser-244) substituted either by } \\
\text { non-phosphorylatable Ala/Asp/Tyr residues }\end{array}$ & $\begin{array}{l}\text { Mutant viruses were defective in cell-to-cell and long distance } \\
\text { movement, suggesting the vital regulatory role of PVA CP } \\
\text { phosphorylation by CK2 in virus infection. However, at } 20 \mathrm{dpi} \text {, } \\
\text { weak GFP fluorescence appeared in the upper leaves. Reverse } \\
\text { transcriptase-mediated PCR and nucleotide sequencing revealed a } \\
\text { reverse mutation from Ala- } 243 \text { to Thr- } 243 \text {, indicating that the virus } \\
\text { had to restore at least one CK2 site to remain viable. }\end{array}$ & {$[34]$} \\
\hline Potato virus Y PVY-N605 & $\begin{array}{l}\text { Amino acid changes within CP: } \\
\text { - } \quad \mathrm{Asn}_{25} \rightarrow \mathrm{Ile}_{25} \\
\text { - } \quad \mathrm{Glu}_{68} \rightarrow \mathrm{Lys}_{68}\end{array}$ & $\begin{array}{l}\text { - } \text { Asn }_{25} \text { Ile mutation significantly increased PVY accumulation } \\
\text { and competitiveness in tobacco but decreased its } \\
\text { competitiveness in potato } \\
\text { - Glu } \\
\text { in the absence of competition in potato but strongly decreased } \\
\text { its competitiveness in that host }\end{array}$ & [35] \\
\hline
\end{tabular}


Table 1. Cont.

\begin{tabular}{|c|c|c|c|}
\hline Virus & Genome Manipulation & Findings & Reference \\
\hline $\begin{array}{l}\text { Tobacco vein banding mosaic } \\
\text { virus TVBMV HN39 }\end{array}$ & $\begin{array}{l}\text { Amino acid substitution of } R_{182} \rightarrow I_{182} \text { and } D_{198} \rightarrow K_{198} \text { in } \\
\text { FR182NK and CD198N motifs of HC-Pro respectively }\end{array}$ & $\begin{array}{l}\text { Mutation of R182I/D198K reduced symptoms and virus } \\
\text { accumulation of pTVBMV in inoculated Nicotiana benthamiana } \\
\text { plants significantly, indicating a role of the two amino acids in } \\
\text { regulating virulence of TVBMV. }\end{array}$ & [36] \\
\hline Soybean mosaic virus SMV-G7d & $\begin{array}{l}\text { Amino acid changes: } \\
\text { - } \quad \mathrm{Lys}_{64} \rightarrow \mathrm{Arg}_{64} \text { in P1 } \\
\text { - } \quad \mathrm{Gln}_{472} \rightarrow \mathrm{Arg}_{472} \text { in HC-Pro } \\
\text { - } \quad \mathrm{Val}_{823} \rightarrow \mathrm{Met}_{823}, \mathrm{Met}_{915} \rightarrow \mathrm{Val}_{915}, \mathrm{Lys}_{953} \rightarrow \mathrm{Glu}_{953}, \\
\mathrm{Ala}_{1112} \rightarrow \mathrm{Val}_{1112} \text { in P3 } \\
\text { - } \quad \mathrm{Val}_{2842} \rightarrow \mathrm{Met}_{2842} \text { in CP }\end{array}$ & $\begin{array}{l}\text { Long-term passage of progenies of molecularly cloned SMV } \\
\text { strain G7 in Rsv1-genotype soybean resulted in an emergence } \\
\text { of a mutant, SMV-G7d. A total of seven amino acid } \\
\text { substitutions in SMV-G7d genome lead to its incapability in } \\
\text { provoking either Rsv1-mediated lethal systemic hypersensitive } \\
\text { response or PR-1 protein gene transcript upregulation as } \\
\text { parental SMV-G7 and thus evade an R-mediated recognition. }\end{array}$ & {$[37]$} \\
\hline Soybean mosaic virus & $\begin{array}{l}\text { Amino acid substitution of } \mathrm{N}_{286} \rightarrow \mathrm{D}_{286} \text { in HC-Pro of SMV } \\
\text { A297-12 }\end{array}$ & $\begin{array}{l}\text { The change N286D reduced silencing suppressor activity of } \\
\text { SMV A297-12. }\end{array}$ & {$[38]$} \\
\hline $\begin{array}{l}\text { SMV A297-12,SMV A297-13, } \\
\text { SMV } 413\end{array}$ & $\begin{array}{l}\text { Substitution of the HC-Pro in SMV } 413 \text { infectious clone } \\
\text { with that of: } \\
\text { - } \quad \text { A297-12 (HC-Pro(L54, N286, D369) }) \text { producing } \\
\text { SMV 413-HC-12 } \\
\text { - } \quad(\text { HC-Pro }(\text { F54, D286, N369) }) \text { producing SMV 413-HC-13 }\end{array}$ & $\begin{array}{l}\text { RNA accumulation of SMV } 413-\mathrm{HC}-13 \text { was reduced to less than } \\
3 \% \text { of the level of SMV } 413-\mathrm{HC}-12 \text { at } 10 \mathrm{dpi} \text { but increased to } \\
40 \% \text { of SMV } 413-\mathrm{HC}-12 \text { at } 40 \text { dpi. At } 50 \text { dpi RNA accumulation } \\
\text { of SMV } 413-\mathrm{HC}-13 \text { was similar to that of SMV } 413-\mathrm{HC}-12 \text { and } \\
\text { the D at position } 286 \text { of HC-Pro in SMV } 413-\mathrm{HC}-13 \text { was found } \\
\text { to have reverted to N, indicating the strong selection for } \\
\text { revision to wild type when the mutation was introduced into } \\
\text { SMV } 413 \text { infectious clone. }\end{array}$ & \\
\hline Papaya ringspot virus PRSV-W & $\begin{array}{l}\text { Null mutant pSAHPdelF1 retained first \& last } 5 \text { aa while } \\
\text { pSAHPdelF2 retained first } 2 \text { aa of HC-Pro to maintain the } \\
\text { integrity of P1/HC-Pro proteolytic site. pSAHPdelN54 } \\
\text { contains a deletion of first } 54 \text { aa at HC-Pro N-terminus }\end{array}$ & $\begin{array}{l}\text { Both null mutants (pSAHPdelF1 \& pSAHPdelF2) were } \\
\text { non-infectious in the zucchini host. Infectivity test using } \\
\text { pSAHPdelN54 indicates that deletion of as few as } 54 \text { amino } \\
\text { acids at the N-terminus of HC-Pro is deleterious for PRSV } \\
\text { systemic infection in zucchini. }\end{array}$ & [39] \\
\hline
\end{tabular}




\subsubsection{Role of Point Mutation in Cross Protection Phenomenon}

Cross protection is conferred by pre-infecting the host crops with a mild virus strain to prevent the infection by another severe or closely-related strain of that virus [40]. This strategy is a promising biological method to control plant viruses [41]. However, the availability of natural attenuated strains of plant viruses is limited [42]. Hence, point mutations were intentionally engineered into plant viruses for the development of less virulent strains that could be utilized in cross protection [43]. For example, a lysine in the IDEKK motif and glycine in the HC-Pro C terminus of Papaya ringspot virus (PRSV) were changed to aspartic acid and lysine respectively. Consequently, PRSV mild mutants with a potential to cross-protect Cucumis melo plants against wild type PRSV-W were obtained [44]. Similarly, attenuated isolate M11 of Bean yellow mosaic virus (BYMV) was generated by exchanging an amino acid within the large ORF, leucine with serine. BYMV-M11 mutant conferred a complete cross protection against BYMV isolates from gladiolus, incomplete against BYMV isolates from other hosts, partial against a CIYVV isolate [41]. An arginine and a glutamic acid at positions, 180 and 396 in the Zucchini yellow mosaic virus (ZYMV) HC-Pro were substituted with isoleucine and asparagine respectively. The attenuated mutants were found to induce only mild symptoms with recovering and protected squash plants completely against the severe Taiwan strain, ZYMV TW-TN3 [42]. Another mild isolate of ZYMV, ZYMV-AG, was also generated through a substitution of isoleucine for arginine within the conserved FRNK motif of HC-Pro. Cucurbit plants inoculated with ZYMV-AG mutant were protected against the infection by severe ZYMV-NAT and ZYMV-CA isolates [45].

\subsection{Virus/Host Interaction}

Mutagenesis studies on potyvirus infectious clones allowed the mapping of viral determinants responsible for viral genome replication, local and systemic movement of virus, symptomatology and host species range [46] (Table 2). This knowledge facilitates the understanding of complex processes underlying interactions between viral and host factors during a viral infection in plants [1].

\subsubsection{Viral Determinants}

The differential infectivity of UK 1 and JPN 1 strains of TuMV in Ethiopian mustard was studied to map the viral determinants involved [47]. Isolate UK 1 causes a systemic infection in the host while JPN 1 does not. UK 1 and JPN 1 recombinant viruses were made by exchanging the amino acids found in one isolate to that in the other isolate at several positions within the P3 C-terminal domain, leading to the identification of two adjacent positions (1099 and 1100) in TuMV-JPN 1 as the main resistance determinants. GFP-tagged viruses were also constructed to analyse the resistance of Ethiopian mustard to isolate JPN 1. Consequently, both inoculated and non-inoculated leaves showed a virus-induced fluorescence in separate areas, indicating that the non-host resistance is only apparent. In another previous study, the NIb protein of Potato virus Y, PVY-SON41 was demonstrated as the avirulence factor corresponding to Pvr resistance gene in pepper. A single substitution of adenosine nucleotide to guanosine at position 8424 in that region is sufficient for the virulence [48]. 
Table 2. List of molecular determinants mapped in potyviral genomes through reverse genetics method.

\begin{tabular}{|c|c|c|c|c|}
\hline Virus & Genome Manipulation & Application & Findings & Reference \\
\hline $\begin{array}{l}\text { Turnip mosaic virus } \\
\text { TuMV }\end{array}$ & $\begin{array}{l}\text { Chimera pXBS78 derived from pXBS7 } \\
\text { contains a fragment of } 8975-9311 \text { residues } \\
\text { from } 3^{\prime} \text { terminal UTR of pXBS8 } \\
\text { Chimera pXBS87 derived from pXBS8 } \\
\text { contains a fragment of } 8975-9253 \text { residues } \\
\text { from } 3^{\prime} \text { terminal UTR of pXBS7 }\end{array}$ & $\begin{array}{l}\text { Genetic determinant } \\
\text { (symptom severity) }\end{array}$ & $\begin{array}{l}\text { pXBS7 induced symptoms in infected tobacco plants that } \\
\text { are indistinguishable from those produced by native TVMV } \\
\text { RNA. In contrast, pXBS78 induced only very mild barely } \\
\text { detectable symptoms in infected plants. The results of } \\
\text { sequence analysis and genome exchange experiments } \\
\text { indicate that a 58-nt segment consisting of patterns of } \\
\text { adenine and uracil residues in the } 3^{\prime} \text { UTR of pXBS8-derived } \\
\text { RNA is responsible for the symptom attenuation phenotype. }\end{array}$ & [31] \\
\hline $\begin{array}{l}\text { Pea seed-borne mosaic } \\
\text { virus PSbMV-P1 \& } \\
\text { PSbMV-P4 }\end{array}$ & $\begin{array}{l}\text { Exchange of } 5^{\prime} \mathrm{UTR}, \mathrm{P} 1 \text { pro and HCpro of } \\
\text { P-1 with the corresponding regions from } \\
\text { P-4 creating: } \\
\text { vP-1(P-4 5'UTR) } \\
\text { vP-1(P-4 P1pro) } \\
\text { vP-1(P-4 HCpro) respectively }\end{array}$ & $\begin{array}{l}\text { Genetic determinant } \\
\text { (seed transmission) }\end{array}$ & $\begin{array}{l}\text { P-1 is highly seed-transmitted whereas P-4 is rarely } \\
\text { seed-transmitted. The seed transmission frequencies of } \\
\text { vP-1(P-4 5'UTR) and vP-1(P-4 HCpro) were reduced to } 50 \% \\
\text { and } 20 \% \text { of vP-1, respectively, while vP-1(P-4 Plpro) was } \\
\text { seed transmitted at the same frequency as vP-1. This } \\
\text { showed that the HC-Pro was a major determinant of seed } \\
\text { transmission while the P1pro showed no } \\
\text { measurable influence. }\end{array}$ & [49] \\
\hline $\begin{array}{l}\text { Tobacco etch virus TEV } \\
\text { HAT \& TEV NW }\end{array}$ & $\begin{array}{l}\text { TEV HAT and TEV NW chimeras with } \\
\text { exchanged coding regions of the P3, the CI, } \\
\text { and the 6-kDa and VPg-NIa proteins }\end{array}$ & $\begin{array}{l}\text { Genetic determinant } \\
\text { (wilting response) }\end{array}$ & $\begin{array}{l}\text { TEV HAT causes wilting in Tabasco pepper whereas TEV } \\
\text { NW is a non-wilting strain. TEV HAT possessed two } \\
\text { wilting determinants: } \\
3^{\prime} \text { one third of the P3 coding region } \\
3^{\prime} \text { end of the CI, the 6-kDa protein and the } 5^{\prime} \text { end of the } \\
\text { VPg-NIa coding regions } \\
\text { Replacement of only one of them with its counterpart from } \\
\text { TEV NW does not alter the wilt phenotype. }\end{array}$ & [50] \\
\hline $\begin{array}{l}\text { Plum pox virus PPV-R \& } \\
\text { PPV-PS }\end{array}$ & $\begin{array}{l}\text { Chimera containing } 3109-3628 \text { coding } \\
\text { region (173 aa) from PPV-PS on PPV-R } \\
\text { background }\end{array}$ & $\begin{array}{l}\text { Genetic determinant } \\
\text { (symptom development) }\end{array}$ & $\begin{array}{l}\text { The region encodes for C-terminal part of } \mathrm{P} 3+6 \mathrm{~K}_{1} \text {, differ at } \\
11 \text { positions between PPV-R and PPV-PS and contains all } \\
\text { information required to transform the R-type into PS-type } \\
\text { symptomatology in Nicotiana clevelandii. }\end{array}$ & [13] \\
\hline $\begin{array}{l}\text { Potato virus Y } \\
\text { PVY-N, PVY-NTN \& } \\
\text { PVY-O }\end{array}$ & $\begin{array}{l}\text { PVY-N/NTN and PVY-N/O chimeras carry } \\
\text { the } 3^{\prime} \text { end of NIb, the whole CP and } 3^{\prime} U T R \\
\text { region of PVYNTN and PVYO, respectively, } \\
\text { in a PVYN genetic background }\end{array}$ & $\begin{array}{l}\text { Genetic determinant } \\
\text { (symptom development) }\end{array}$ & $\begin{array}{l}\text { In five (N. benthamiana, N. tabacum, N. glutinosa, Solanum } \\
\text { tuberosum) of the six hosts, the chimeras induced similar } \\
\text { symptoms to those of PVY }{ }^{\mathrm{N}} \text {. By contrast, in Physalis } \\
\text { floridana, the N/O hybrid caused symptoms similar to those } \\
\text { of the } 3^{\prime} \mathrm{NIb}-\mathrm{CP} \text {-donating PVY strain, thus suggesting } \\
\text { symptom determinants to be different even between strains } \\
\text { of the same virus species in a particular host. }\end{array}$ & [51] \\
\hline
\end{tabular}


Table 2. Cont

\begin{tabular}{|c|c|c|c|c|}
\hline Virus & Genome Manipulation & Application & Findings & Reference \\
\hline $\begin{array}{l}\text { Potato virus } Y \\
\text { PVYN-605 \& }^{\mathrm{N}} \text { PVYO-139 }^{\mathrm{O}}-1\end{array}$ & 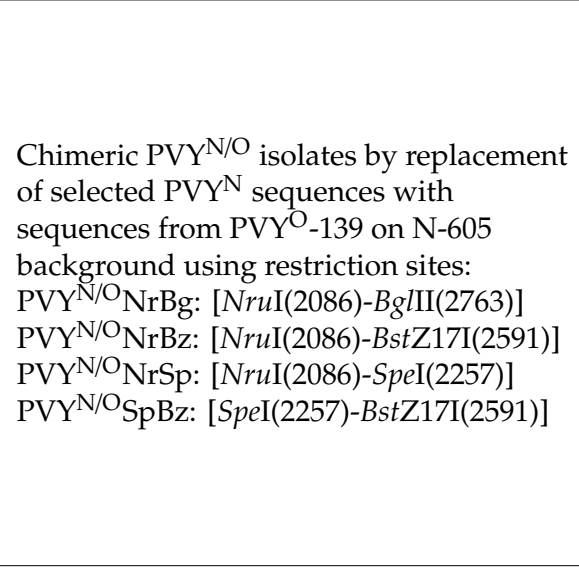 & $\begin{array}{l}\text { Genetic determinant } \\
\text { (symptom development) }\end{array}$ & 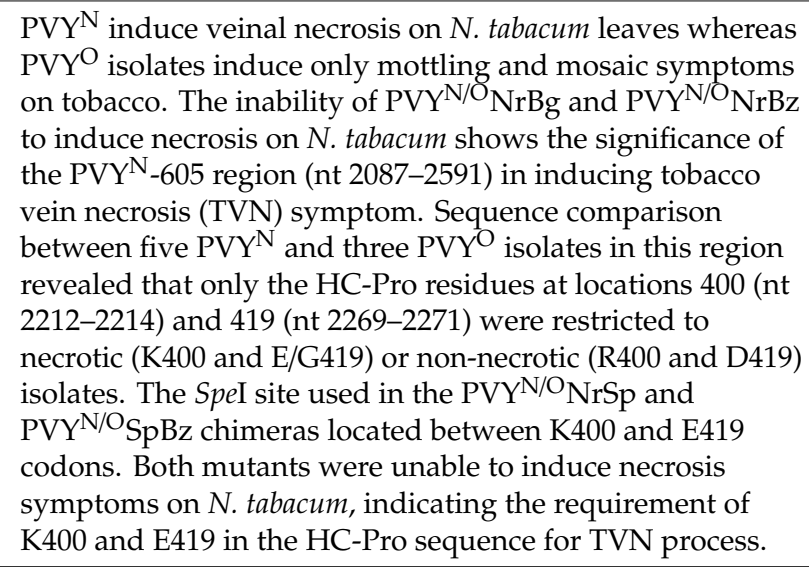 & {$[52]$} \\
\hline $\begin{array}{l}\text { Potato virus } Y \\
\text { PVYN }_{-605} \& \\
\text { PVY }_{-139}\end{array}$ & $\begin{array}{l}\text { Amino acid substitution of } \mathrm{N}_{339} \text { in } \\
P V Y_{-}-605 \text { with sequence }\left(\mathrm{D}_{339}\right) \text { from } \\
\text { PVY } \\
\text { PY-139 }\end{array}$ & $\begin{array}{l}\text { Genetic determinant } \\
\text { (symptom development) }\end{array}$ & $\begin{array}{l}\mathrm{PVY}^{\mathrm{N}} \text { induce veinal necrosis on } N \text {. tabacum leaves whereas } \\
\mathrm{PVY}^{\mathrm{O}} \text { isolates induce only mottling and mosaic symptoms } \\
\text { on tobacco. } \mathrm{N}_{339} \mathrm{D} \text { mutant resulted in the modification of } \\
\text { the PVYN biological property, from necrotic to mosaic } \\
\text { symptoms on infected N. tabacum. }\end{array}$ & {$[53]$} \\
\hline $\begin{array}{l}\text { Pea seed-borne mosaic } \\
\text { virus PSbMV-DPD1 \& } \\
\text { PSbMV-NY }\end{array}$ & $\begin{array}{l}\text { DPD1(CP-NY) and NY(CP-DPD1) } \\
\text { chimeras with exchanged CP } \\
\text { p35S-NY(S47P) carries amino acid } \\
\text { substitution of Ser } 47 \text { in NY CP with } \text { Pro }_{47} \\
\text { as in DPD1 CP and vice versa in } \\
\text { p35S-DPD1(P47S) }\end{array}$ & $\begin{array}{l}\text { Genetic determinant } \\
\text { (long-distance } \\
\text { movement) }\end{array}$ & $\begin{array}{l}\text { DPD1 spreads to uninoculated leaves, whereas NY is } \\
\text { restricted to the inoculated leaves. DPD1(CP-NY) was } \\
\text { restricted to inoculated leaves whereas NY(CP-DPD1) } \\
\text { infected C. quinoa systemically. Hence, CP was identified as } \\
\text { the determinant of long-distance movement. Ser } 47 \rightarrow \text { Pro }_{47} \\
\text { permit systemic spread of the NY(S47P) mutant whereas } \\
\text { Pro }{ }_{47} \rightarrow \text { Ser }_{47} \text { restricted DPD1(P47S) reverse mutant to } \\
\text { inoculated leaves. }\end{array}$ & [54] \\
\hline $\begin{array}{l}\text { Turnip mosaic virus } \\
\text { TuMV-UK1 }\end{array}$ & $\begin{array}{l}\text { Nucleotide substitution of } A_{5056} \rightarrow G_{5056} \\
(p 35 \text { Tunos } 5056 A>G) \\
\text { and } A_{5570} \rightarrow G_{5570}(p 35 \text { Tunos } 5570 A>G) \text { in } \\
\text { the } C I \text { coding region of p35Tunos }\end{array}$ & $\begin{array}{l}\text { Pathogenicity } \\
\text { determinant }\end{array}$ & $\begin{array}{l}\text { TuMV UK } 1 \text { is incapable of infecting lines R } 4 \text { (possessing the } \\
\text { resistance gene TuRB01). Unlike the wild-type TuMV UK } 1 \\
\text { derived from p35Tunos, recombinant viruses containing the } \\
\text { mutations infected the line N-o- } 1 \text { (possessing TuRB01), } \\
\text { confirming that either single nucleotide change is sufficient } \\
\text { to overcome TuRB01 resistance. }\end{array}$ & [55] \\
\hline
\end{tabular}


Table 2. Cont

\begin{tabular}{|c|c|c|c|c|}
\hline Virus & Genome Manipulation & Application & Findings & Reference \\
\hline $\begin{array}{l}\text { Lettuce mosaic virus } \\
\text { LMV-0 \& LMV-E }\end{array}$ & $\begin{array}{l}\text { LMV-0 and LMV-E chimeras with } \\
\text { exchanged HC-Pro and } 3^{\prime} \text { half coding } \\
\text { regions }\end{array}$ & $\begin{array}{l}\text { Pathogenicity } \\
\text { determinant }\end{array}$ & $\begin{array}{l}\text { LMV-E could overcome the protection afforded by the } \\
\text { resistance genes } m o 1^{1} \text { or } m o 1^{2} \text {, resulting in systemic mosaic } \\
\text { symptoms whereas LMV-0 could not. HC-Pro of LMV-E is } \\
\text { responsible for causing severe stunting and necrotic mosaic } \\
\text { in susceptible cultivars. In contrast, the ability to overcome } \\
\text { mo1 resistance was mapped to the } 3^{\prime} \text { half of the LMV-E } \\
\text { genome. }\end{array}$ & [56] \\
\hline $\begin{array}{l}\text { Turnip mosaic virus } \\
\text { TuMV-UK1 }\end{array}$ & $\begin{array}{l}\text { Mutation at position }+3394 \text { (P3 sequence) } \\
\text { and }+5447 \text { (CI coding region) in TuMV-UK } \\
1 \mathrm{M} 3\end{array}$ & $\begin{array}{l}\text { Pathogenicity } \\
\text { determinant }\end{array}$ & $\begin{array}{l}\text { Mutation in the P3 protein defeated immunity conferred by } \\
\text { resistance gene TuRB04. TuRB04 is epistatic to the second } \\
\text { gene, TuRB05. Mutation in the CI breaks TuRB05 resistance } \\
\text { in Brassica napus differential line } 165 \text {. }\end{array}$ & [57] \\
\hline $\begin{array}{l}\text { Pea seed-borne mosaic } \\
\text { virus PSbMV-P1 \& } \\
\text { PSbMV-P4 }\end{array}$ & $\begin{array}{l}\text { PSbMV-P1 and PSbMV-P4 chimeras with } \\
\text { exchanged VPg coding region }\end{array}$ & Virulence determinant & $\begin{array}{l}\text { PSbMV-P4 is fully infectious in the } s b m-1 / s b m-1 \text { genotype } \\
\text { whereas PSbMV-P1 is not. P-1/P-4 recombinant clones with } \\
\text { the VPg (21-kDa) from P-4 was capable in overcoming } s b m-1 \\
\text { resistance, while chimeric clones containing the P-1 VPg } \\
\text { domain were not infectious to } s b m-1 / s b m-1 \text { peas. VPg acts as } \\
\text { the PSbMV determinant of infectivity in } s b m-1 / s b m-1 \text { peas. }\end{array}$ & {$[58]$} \\
\hline \multirow{2}{*}{$\begin{array}{l}\text { Potato virus } Y \\
\text { PVY-LYE84.2, } \\
\text { PVY-LYE84, PVY-SON41 }\end{array}$} & \multirow{2}{*}{$\begin{array}{l}\text { Chimera LYE84.2×VPgLYE84: central part } \\
\text { of VPg (Nt 5762-6129) in PVY-LYE84.2 } \\
\text { exhanged with respective region from } \\
\text { PVY-LYE84 } \\
\text { LYE84.2×VPgSON41 \& } \\
\text { SON41×VPgLYE84.2 chimeras with } \\
\text { exchanged central part of VPg (Nt } \\
5923-6118)\end{array}$} & \multirow{2}{*}{ Virulence determinant } & $\begin{array}{l}\text { SON41×VPgLYE84.2 chimera and PVY-LYE84.2 } \\
\text { systemically infected PI247087, Lycopersicon hirsutum } \\
\text { carrying pot-1 resistance gene while LYE84.2×VPgLYE84 } \\
\text { does not. Difference identified within the exchanged region } \\
\text { between both isolates is that, LYE84.2 contains Arg at amino } \\
\text { acid position } 119 \text { whereas LYE84 contains His instead. } \\
\text { Hence, Arg } 119 \text { is responsible for the virulence toward pot-1. }\end{array}$ & \multirow[t]{2}{*}{ [59] } \\
\hline & & & $\begin{array}{l}\text { Chimera LYE84.2×VPgSON41 and PVY-SON41 systemically } \\
\text { infected all three Capsicum annuum genotypes including } \\
\text { Yolo Y and Florida VR2 carrying pot-pvr } 2^{1} \mathcal{E} \text { pvr } 2^{2} \\
\text { resistance genes while SON41xVPgLYE } 84.2 \text { infected Yolo } \\
\text { Wonder, susceptible cultivar only. SON } 41 \text { and LYE84.2 } \\
\text { differ by five amino acids within the exchanged region (at } \\
\text { positions } 105,115,119,121,123 \text { ) which suggested to affect } \\
\text { the virulence towards pvr } 2^{1} \mathcal{E} \text { pvr } 2^{2} \text { genes. }\end{array}$ & \\
\hline
\end{tabular}


Table 2. Cont

\begin{tabular}{|c|c|c|c|c|}
\hline Virus & Genome Manipulation & Application & Findings & Reference \\
\hline $\begin{array}{l}\text { Potato virus Y } \\
\text { PVY-SON41p }\end{array}$ & $\begin{array}{l}\text { Amino acid substitution of } \mathrm{D}_{119} \rightarrow \mathrm{N}_{119} \text { \& } \\
\mathrm{H}_{121} \rightarrow \mathrm{N}_{121} \text { in VPg cistron }\end{array}$ & Virulence determinant & $\begin{array}{l}\text { Virulence of PVY towards an allelic series (pvr } 2^{1} \text {, pvr } 2^{2} \text {, pvr }{ }^{3} \\
\text { resistance alleles) at the } p v r 2 \text { locus in pepper genotypes are related } \\
\text { to variations in the VPg. PVY isolates; To72, CAA } 82 \text { and EP03 } \\
\left(\mathrm{H}_{119}, \mathrm{~N}_{121} \text { ) displayed the closest VPg sequence compared to }\right. \\
\text { SON41p }\left(\mathrm{D}_{119}, \mathrm{H}_{121}\right) \text { and its mutants virulent towards } p v r 2^{2}, \\
\text { differing by two amino acids. Selective pressures by the } p v r 2^{1} \text { and } \\
\text { pvr } 2^{3} \text { alleles accelerate the fixation of the first mutations required } \\
\text { for virulence towards pvr } 2^{2} \text {. The use of } p v r 2^{1} \text { or } p v r 2^{3} \text { could } \\
\text { contribute to selection for the reverse mutant } \mathrm{D}_{119} \mathrm{~N} \text { (by fixing the } \\
\mathrm{N}_{121} \mathrm{H} \text { mutation), while } p v r 2^{3} \text { could select for the reverse mutation } \\
\mathrm{H}_{121} \mathrm{~N} \text { (by fixing the } \mathrm{N}_{119} \mathrm{D} \text { mutation). These mutants then need } \\
\text { only single-nucleotide substitution for virulence against } p v r 2^{2} \text {. }\end{array}$ & {$[60]$} \\
\hline $\begin{array}{l}\text { Potato virus Y } \\
\text { PVY-SON41 }\end{array}$ & $\begin{array}{l}\text { Nucleotide substitution of } A_{8424} \rightarrow G_{8424} \\
\text { in NIb cistron of SON41p }\end{array}$ & Virulence determinant & $\begin{array}{l}\text { NIb protein of PVY was the avirulence factor corresponding to } \\
\text { resistance gene Pvr4. However, } A_{8424} \rightarrow G_{8424} \text { substitution was } \\
\text { sufficient for virulence and imposed a high competitiveness cost to } \\
\text { the virus against an avirulent PVY variant in plants lack of Pvr4. } \\
\text { The only observed possibility of the virulent mutant to increase its } \\
\text { fitness was through the } G_{8424} \text { A reversion, which simultaneously } \\
\text { led to a reversion of the virus virulence, strengthening the high } \\
\text { durability potential of the Pvr4 resistance in field. }\end{array}$ & {$[48]$} \\
\hline $\begin{array}{l}\text { Turnip mosaic virus } \\
\text { TuMV-UK1 \& } \\
\text { TuMV-JPN } 1\end{array}$ & $\begin{array}{l}\text { U(2511-3767)J+GFP chimera with } \\
2511-3767 \text { (P3 protein) from JPN1 in UK1 } \\
\text { background } \\
\text { UK } 1 \text { and JPN } 1 \text { chimeras with exchanged } \\
1099-1100 \text { amino acids }\end{array}$ & Resistance determinant & $\begin{array}{l}\text { TuMV-UK } 1 \text { able to infect Ethiopian mustard while isolate JPN } 1 \\
\text { was not. GFP tagged viruses showed that Ethiopian mustard } \\
\text { conferred an apparent non-host resistance (NHR) to JPN 1, as } \\
\text { virus-induced fluorescence could be found in discrete areas of both } \\
\text { inoculated and non-inoculated leaves. Two adjacent positions (1099 } \\
\text { \& 1100) in the C-terminal domain of P3 were identified as the } \\
\text { resistance determinants in TuMV-JPN } 1 \text {. }\end{array}$ & [47] \\
\hline $\begin{array}{l}\text { Turnip mosaic virus } \\
\text { TuMV-UK1 \& } \\
\text { TuMV-CDN } 1\end{array}$ & $\begin{array}{l}\text { UK } 1 \text { P3 I153F carries amino acid } \\
\text { substitution of Ile }{ }_{153} \text { in P3 with Phe } 153 \text { as } \\
\text { in CDN } 1 \text { and vice versa in CDN } 1 \text { P3 } \\
\text { F153I }\end{array}$ & Avirulence determinant & $\begin{array}{l}\text { The resistance gene TuRB03, in the B. napus line } 22 \mathrm{~S} \text {, is effective } \\
\text { against CDN } 1 \text { but not UK } 1 \text {. Virus derived from UK } 1 \text { P3 I153F } \\
\text { completely prevented any viral infection, affecting the phenotype } \\
\text { of UK } 1 \text { on } B \text {. napus line } 22 \text {. Virus derived from CDN } 1 \text { P3 F153I } \\
\text { was virulent and infected line } 22 S \text { with systemic mosaic symptoms. } \\
\text { This indicate the role of P3 residue at position } 153 \text { in avirulence. }\end{array}$ & {$[61]$} \\
\hline
\end{tabular}




\subsubsection{Host Specificity}

The differential responses of UK 1 and JPN 1 strains of TuMV in different hosts; brassicas (Ethiopian mustard, Indian mustard, turnip) and radish cultivars (Icicle, round red radish with a white tip (RRRWWT), Daikon) were investigated [62]. Although both infectious clones caused infection in all three brassicas, the symptoms induced were observed to be different from each other. In the case of radish, TuMV-JPN 1 infected European types (Icicle \& RRRWWT) but not Japanese Daikon radish. In contrast, TuMV-UK 1 was not able to infect any radish type, showing its distinct biological properties compared to UK 1 isolate. In addition, two more isolates of TuMV, Tu-2R1 (pTuR1) and Tu-3 $(\mathrm{pTuC})$ also exhibited distinct host-specific infection phenotype and symptomatology in cabbage and radish [63]. Tu-2R1 systemically infect Japanese radish, inducing mosaic symptoms apart from very mild chlorotic mottle in cabbage (Brassica oleracea L.). Meanwhile, Tu-3 induced systemic chlorotic and ringspot symptoms in infected cabbage but not radish. The genomic region encoding $\mathrm{C}$ terminus of HC-Pro, all of $\mathrm{P} 3$ and $\mathrm{N}$ terminus of $6 \mathrm{~K} 1$ was exchanged between pTuC and pTuR1 chimeras. The only difference between pTuR1 and pTuC was identified within the amino acid sequence of P3 gene. Hence, P3 gene was suggested to be involved in the differential phenotypes caused by TuMV isolates in both hosts.

Host specificity of two different Johnsongrass mosaic virus (JGMV) strains, Johnsongrass infecting JGMV-Jg and Krish strain JGMV-Kr, was studied. Transcripts of JGMV-Jg full-length chimera containing coat protein sequences from JGMV-Kr were infectious in Krish resistant sorghums, thus confirming the role of JGMV-Kr coat protein in its host specificity [64]. Similarly, PRSV strain belongs to type $\mathrm{p}$ (PRSV P) possessed different biological characteristics compared to type W (PRSV W). Host species range of PRSV W is limited to Chenopodiaceae and Cucuribitaceae families whereas PRSV P infects plants in papaya family (Caricaceae) additionally [65]. Host assays using recombinant viruses generated between PRSV P-YK and PRSV W-CI in combination with site-directed mutagenesis revealed that lysine amino acid at position 27 in NIaPro acts as the host specificity determinant in PRSV for infecting papaya [66]. A single amino acid mutation, either lysine to aspartic acid or vice versa at position 27 is sufficient for the switching of PRSV host range between non-papaya infecting and papaya-infecting respectively [67].

\subsubsection{Virus-Host Cell Machinery Interaction}

Naderpour and Johansen [68] studied Bean common mosaic virus (BCMV) interaction with its host, bean genotypes carrying different combinations of resistance genes $(b c-u, b c-1, b c-2, b c-3$, and $I)$. The experimental plants were agroinoculated with an infectious clone of RU1 strain, pCA-RU1-GUS containing UidA gene. In situ histochemical GUS assays revealed that DW, The Prince, CRM, SP, and SGR cultivars (carrying $b c-u$ resistance gene) were all systemically infected. However, the genotypes carrying the I gene alone (Widusa) or in combination with $b c-1$ (Topcrop, ITG), bc-12/bc-22 (IVT-7233), and $b c-3$ (USCR-7, Raven) showed only a weak blue staining. These resistance responses against BCMV-RU1 are largely in agreement with previous results obtained through immunological method and symptom descriptions based analysis [69]. The study suggested that resistance gene I conferred a complete protection against BCMV-RU1 while $b c$-genes do not provide any. Besides that, the host defence response of cucurbit genotype, Dina-1 against ZYMV-NAA potyvirus has also been focused on previously [70]. Switches in amino terminus of the virus coat protein breaks Dina-1 resistance against ZYMV-NAA, suggesting its resistance gene product to be involved in direct interaction with the substituted region.

To learn more on mechanisms of interrelation between potyvirus and host, the impact induced by TuMV infection on the endomembranes of host early secretory pathway was examined [71]. TuMV infection caused the endoplasmic reticulum (ER), Golgi apparatus, COPII coatamers, and chloroplasts being amalgamated as a perinuclear globular structure that included viral protein, $6 \mathrm{~K}_{2}$ vesicles too. TuMV $6 \mathrm{~K}_{2}$ fused to photoactivable GFP (PAGFP) was used to monitor the vesicle movement. Viral egress is shown to begin with the budding of $6 \mathrm{~K}_{2}$ vesicles at ER export site in the 
globular structure. The virus then travels to plasma membrane and plasmodesmata to be delivered into neighboring cells. Some peripheral vesicles were also observed to be recycled back to the globular structure. This indicated a functional linkage between the peripheral vesicles and perinuclear structure. Although the Golgi apparatus and ER lost their organization due to the amalgamation, they were still connected to the host secretory pathway (ER-to-Golgi transport). The importance of this connection was investigated by inhibiting the pathway. As a result, the disruption enhanced the clustering of peripheral $6 \mathrm{~K}_{2}$ vesicles with COPII coatamers, leading to an inhibition of cell-to-cell movement of virus. This suggests the requirement of a functional secretory pathway for a successful intercellular propagation of TuMV.

Along with these host-viral factor interactions, the interplay between Tobacco etch virus (TEV) and Arabidopsis thaliana proteins was also investigated [72]. An affinity polypeptide Twin-Strep-tag (TST) was inserted between codons of VPg and NIaPro domains in the TEV NIa to facilitate the study. A total of 232 different Arabidopsis thaliana proteins targeted by viral proteins were identified through affinity purification followed by mass spectrometry analysis (AP-MS). VPg and NIaPro specifically targeted 89 and 76 of these proteins, respectively. Overall, a total of 67 proteins targeted by both domains were considered to be the targets of full-length NIa.

\subsection{Viral Proteins}

Apart from the mature proteins, proteolytic processing of the potyviral polyprotein also produced multiple partially processed intermediates [73]. The different potyviral proteins act in a coordinated and interdependent manner. About 33 interactions were identified between potyviral proteins through a testing of 58 protein combinations in planta [74,75]. This broad network of interrelations with different viral and host proteins contributes to the multifunctional nature of potyviral proteins [76].

\subsubsection{Functional Importance}

Potyviral HC-Pro and CP proteins were reported to have a crucial role in efficient aphid transmission [28]. In line with that, a change of lysine amino acid to glutamic acid at the position 307, within Zinc-finger motif of HC-Pro completely abolished insect transmission activity of Tobacco vein mottling virus, TVMV-WT. The mutation suggested might have altered the motif structure and thus the binding property of HC-Pro too [32]. Likewise, a TEV mutant, TEV-2del lacking 207 nucleotides in HC-Pro sequence exhibited an aphid-non-transmissible phenotype. However, its transmission activity was restored partially by pre-feeding the aphids on active HC-Pro from PVY. This confirms the helper activity of the N-terminal domain of HC-Pro [11]. A mutation introduced within CDNQLD motif of ZYMV-A HC-Pro also resulted in an almost complete absence of symptoms and partial reduction of viral accumulation [77]. The motif sequence was suggested to be involved in symptomatology or silencing inhibition. On the other hand, when glutamic acid at amino acid position 68 within the $\mathrm{CP}$ of PVY-N605 was substituted with a lysine, aphid transmission of the virus increased by two folds [35].

Seo et al. [78] conducted a yeast two-hybrid system (YTHS) and galactosidase assays to investigate the interaction between CP and HC-Pro in Soybean mosaic virus, SMV-G7H. A highly conserved histidine in the CP C-terminus and an arginine near the cleavage site at HC-Pro C-terminus were mutated and the results obtained showed that both amino acids are necessary to maintain the interaction for a successful transmission of SMV by aphids. Moreover, an amino acid substitution in the DAG motif was found to have disrupted the CP-HC-Pro interaction in YTHS.

\subsubsection{Structural Importance}

In order to figure out the function of $3^{\prime}$-UTRs of potyviruses, the sequences between nucleotide positions 8-42 in the $3^{\prime}$ UTR of a Tobacco vein banding mosaic virus, TVBMV-HN39 infectious clone, pCaTVBMV-GFP were deleted. As a consequence, the mutant caused no systemic infection in inoculated Nicotiana benthamiana plants. According to the RNA secondary structures prediction, the deleted region is able to form a stem-loop (SL) like structure. Progenies derived from TVBMV mutants lacking 
nucleotides between positions 1 and 20 and 15 and 35 within $3^{\prime}$-UTR were found to have restored the $5^{\prime}$-end SL like structures and systemically infected tobacco plants. Hence, the $5^{\prime}$-terminal stem loop was proposed to be neccessary for TVBMV systemic infection [79]. Formation of the stem-loop structure by a conserved nucleotide motif in $3^{\prime}$ UTRs of 15 potyviruses including the New Zealand isolate of Clover yellow vein virus (CYVV-NZ) has been reported previously [80].

\subsection{Viral Vectors}

Apart from bacterial and yeast expression systems, the plant viral vectors also provide a fast and efficient approach for synthesis of specific proteins in plant cells [81]. In this context, potyviruses have often been used as gene expression vectors due to some of their advantageous traits [12]. For instance, their rod shape make them less restrictive to accommodate large genome inserts [82]. Furthermore, it is well-known that potyviruses infect all types of plant tissues including seeds [83-85]. Two different insertion sites in potyviruses were exploited for the introduction of target genes, either between P1 and HC-Pro or else between NIb and capsid protein cistrons [86]. These criteria allowed a simultaneous expression of two foreign proteins [87], either as free molecules or fused to viral proteins $[88,89]$.

\subsubsection{Gene Tagging}

Viral vectors are usually tested through an expression of well-analyzable reporter genes in plants [46]. With reference to that, a ZYMV full-length clone containing GUS gene under a Strawberry vein banding virus (SVBV) viral promoter was inoculated into experimental host plants [90] (Table 4). The GUS gene was found to be expressed stably in infected tobacco plants, indicating the applicability of ZYMV infectious clone as a viral vector and the functionality of the novel SVBV promoter in driving ZYMV infection. Apart from that, tagging a TEV clone with GUS marker gene eased the monitoring of virus replication and spread following infection through a simple histochemical assay in situ [91] (Table 4).

\subsubsection{Expression of Biologically Active Polypeptide}

The potential of Brome mosaic virus (BMV) to be developed into a plant virus vector was successfully demonstrated in 1986 [92]. Since then, massive efforts have been taken in constructing vector systems with plant viruses for the expression of foreign genes in planta (Table 3). The main goal of plant genetic modifications by incorporating transgenes is to change crop properties, leading to increased yields or higher quality of the agricultural products. For instance, a soybean glutamine synthetase (GS) together with GFP were expressed using a CIYVV-vector system, resulting in glufosinate herbicide tolerance and early flowering of legume plants [84]. In a similar way, the expression of endoglucanase D (EngD) in N. benthamiana using a Pepper mottle virus, PepMov-based vector led to an increased senescence along with milder symptoms [93]. Another purpose of developing transgenic plants is to produce different foreign substances of protein nature [46]. For an example, the nucleocapsid proteins (NPs) of tospoviruses were expressed by a ZYMV vector in squash plants. Those NPs act as immunogens for the production of highly specific polyclonal antiserum and monoclonal antibody [81]. Likewise, a transcription factor, Rosea1 tagged infectious clone of PVY was developed, conferring benefits to molecular farming by rapidly produced larger amounts of anthocyanins in biofactory crops [94]. 
Table 3. Applications of potyviral vectors for the expression of biologically active polypeptides.

\begin{tabular}{|c|c|c|c|c|}
\hline Virus & Genome Manipulation & Application & Findings & Reference \\
\hline $\begin{array}{l}\text { Clover yellow vein virus } \\
\text { CIYVV }\end{array}$ & $\begin{array}{l}\text { pCIYVV-GFP-GS contains a } g f p \text { gene and } \\
\text { soybean glutamine synthetase (GS) } \\
\text { inserted between P1 and HC-Pro. Junctions } \\
\text { between the inserted proteins contained } \\
\text { the protease cleavage recognition sites }\end{array}$ & Enhance crop quality & $\begin{array}{l}\text { Western blot analyses showed that GFP and GS have been } \\
\text { precisely excised from the viral polyprotein with the viral } \\
\text { proteases (P1 and NIa). Co-ordinate expression of multiple } \\
\text { genes can be achieved by proteolytic cleavage of a } \\
\text { polyprotein. The plants expressing GS and GFP became } \\
\text { tolerant to the herbicide glufosinate, and flowered early }\end{array}$ & {$[84]$} \\
\hline Plum pox virus PPV-D & $\begin{array}{l}\text { pICPPV-NK-VP60 contains the VP06 } \\
\text { structural protein of Rabbit hemorrhagic } \\
\text { disease virus (RHDV) inserted between the } \\
\text { NIb and CP }\end{array}$ & Expression of antigen & $\begin{array}{l}\text { Immunization of the natural host of RHDV, rabbits with } \\
\text { extracts of Nicotiana clevelandii plants infected with the } \\
\text { PPV-NK-VP60 chimera induced an efficient immune } \\
\text { response that protected animals against a lethal challenge } \\
\text { with RHDV. }\end{array}$ & [88] \\
\hline $\begin{array}{l}\text { Zucchini yellow mosaic } \\
\text { virus ZYMV TW-TN3 }\end{array}$ & $\begin{array}{l}\text { ZWBNV-N recombinant contains } \\
\text { nucleocapsid protein (NP) ORF of } \\
\text { Watermelon bud necrosis virus inserted } \\
\text { between the P1 and HC-Pro. }\end{array}$ & Expression of antigen & $\begin{array}{l}\text { Six histidine residues and an NIa protease cleavage site } \\
\text { were added at the C-terminal region of the inserts to } \\
\text { facilitate purification and process of free form of the } \\
\text { expressed NPs, respectively. The ZYMV-expressed WBNV } \\
\text { NP was purified from extracts of the infected squash plants } \\
\text { and was used as an immunogen for production of specific } \\
\text { antiserum in a rabbit and monoclonal antibodies in mice. }\end{array}$ & [81] \\
\hline $\begin{array}{l}\text { Papaya ringspot virus } \\
\text { PRSV-W }\end{array}$ & $\begin{array}{l}\text { pVD2EDIII contains a histidine tagged } \\
\text { dengue E protein domain III (DENV } 2 \text { E) } \\
\text { inserted between the P1 and HC-Pro }\end{array}$ & Expression of antigen & $\begin{array}{l}\text { The construct was designed to generate a discrete antigen } \\
\text { moiety (D2EDIII) after proteolytic processing. However, the } \\
\text { E protein insert was fused to the PRSV P1 protein, } \\
\text { suggesting inefficient protease processing at the P1/D2EDIII } \\
\text { junction. Despite the failure, the insert was shown to be } \\
\text { stable over } 2 \text { passages PRSV indicating the vector suitability } \\
\text { and stability for the expression of heterologous proteins in } \\
\text { zucchini plants. }\end{array}$ & [103] \\
\hline Potato virus A PVA-B11 & $\begin{array}{l}\text { PVA vectors containing soluble } \\
\text { resistance-related calcium-binding protein } \\
\text { (sorcin) catechol-O-methyltransferase } \\
\text { (S-COMT) between NIb and CP }\end{array}$ & $\begin{array}{l}\text { Expression of genes } \\
\text { human origin }\end{array}$ & $\begin{array}{l}\text { The inserts caused no adverse effects on viral infectivity and } \\
\text { virulence, and the inserted sequences remained intact in } \\
\text { progeny viruses in the systemically infected leaves. } \\
\text { S-COMT with high levels of enzymatic activity were } \\
\text { produced. However, no sorcin was detected despite the } \\
\text { expected equimolar amounts of the foreign and viral } \\
\text { proteins being expressed as a polyprotein. }\end{array}$ & [104] \\
\hline
\end{tabular}


Table 3. Cont

\begin{tabular}{|c|c|c|c|c|}
\hline Virus & Genome Manipulation & Application & Findings & Reference \\
\hline $\begin{array}{l}\text { Zucchini yellow mosaic } \\
\text { virus ZYMV-AG }\end{array}$ & $\begin{array}{l}\text { Non-pathogenic vector, ZYMV-AGII } \\
\text { carries CMV coat protein (AGII-CMV-CP), } \\
\text { jellyfish GFP (AGII-GFP), uidA (AGII-GUS) } \\
\text { \& human interferon-alpha } 2 \text { (AGII-IFN) } \\
\text { genes inserted into NIb-CP site }\end{array}$ & $\begin{array}{l}\text { Viral coat protein \& } \\
\text { human anti-viral drug }\end{array}$ & $\begin{array}{l}\text { All four constructs infected squash plants and stably expressed } \\
\text { the inserted genes without affecting plant development. } \\
\text { ZYMV-AG vector could mediate the synthesis of a biologically } \\
\text { active IFN in edible cucurbit fruit and leaves. }\end{array}$ & [105] \\
\hline $\begin{array}{l}\text { Zucchini yellow mosaic } \\
\text { virus ZYMV }\end{array}$ & $\begin{array}{l}\text { p35ZYMVDerp } 5 \text { contains Dermatophagoides } \\
\text { pteronyssinus group } 5 \text { allergen (Der p } 5 \text { ) } \\
\text { inserted in between P1 and HC-Pro coding } \\
\text { regions }\end{array}$ & $\begin{array}{l}\text { Expression of mite } \\
\text { allergen }\end{array}$ & $\begin{array}{l}\text { Infectivity assays and immunoblotting revealed that large } \\
\text { quantities of free-form virus-expressed Der p } 5 \text { (vDer p 5) are } \\
\text { produced in the recombinant virus-infected squash plants. } \\
\text { Female mice were orally treated with the vDer p } 5 \text { extract. As a } \\
\text { result, the allergen inhibited Der p 5-specific IgE synthesis and } \\
\text { airway inflammation, clinically relevant to human asthma. This } \\
\text { provides a novel approach for the therapy of allergic asthma. }\end{array}$ & [106] \\
\hline \multirow[b]{2}{*}{$\begin{array}{l}\text { Soybean mosaic virus } \\
\text { SMV-G7H }\end{array}$} & $\begin{array}{l}\text { RNA silencing suppressors } 2 \mathrm{~b} \text { and } \mathrm{p} 19 \\
\text { genes were cloned into pSMV-MCS } \\
\text { between the P1 and HC-Pro cistrons } \\
\text { (pSMV-2b and pSMV-p19 respectively) }\end{array}$ & $\begin{array}{l}\text { Expression of RNA } \\
\text { silencing suppressors }\end{array}$ & $\begin{array}{l}\text { Severe symptoms including stunting, extensive leaf } \\
\text { deformation and shrivelling was detected in either pSMV-2b or } \\
\text { pSMV-p19 infected soybean, with the accumulation of SMV } \\
\text { RNAs and CP similar to that in plants infected with pSMV-GFP. }\end{array}$ & \multirow[t]{2}{*}{ [87] } \\
\hline & $\begin{array}{l}\text { Partial forward sequence ( } 567 \mathrm{bp}) \text { and } \\
\text { partial reverse sequence }(282 \mathrm{bp}) \text { of were } \\
\text { inserted into pSMV-MCS between the P1 } \\
\text { and HC-Pro cistrons (pSMV-spPDSfw and } \\
\text { pSMV-spPDSrv respectively) }\end{array}$ & $\begin{array}{l}\text { Expession of phytoene } \\
\text { desaturase (PDS) }\end{array}$ & $\begin{array}{l}\text { Successful infection of both clones and stable insertion of the } \\
\text { partial PDS genes within viral genomes were shown. However, } \\
\text { there is no photobleached leaves in plants infected with } \\
\text { pSMVspPDSfw/pSMV-spPDSrv could be observed, indicating } \\
\text { that the PDS gene was not successfully silenced by the clones. } \\
\text { This was expected since SMV encoded a strong silencing } \\
\text { suppressor, HC-Pro. }\end{array}$ & \\
\hline Potato virus Y PVY-RB & $\begin{array}{l}\text { pGPVY-Ros1 contains a Antirrhinum majus } \\
\text { Rosea1 transcription factor between NIb \& } \\
\text { CP }\end{array}$ & Regulatory factor & $\begin{array}{l}\text { PVY-Ros } 1 \text { induced the accumulation of of antioxidant } \\
\text { anthocyanins ( } 275 \mathrm{mg} \text { per } 100 \mathrm{~g} \text { of fresh weight) in biofactory } \\
\text { plants in only } 12 \text { days. }\end{array}$ & [94] \\
\hline $\begin{array}{l}\text { Pepper mottle virus } \\
\text { PepMoV-Vb1 }\end{array}$ & $\begin{array}{l}\text { pSP6PepMoVVb1/EngD contains an } \\
\text { endoglucanase D (EngD) from Clostridium } \\
\text { cellulovorans inserted between sequences } \\
\text { encoding NIb and CP }\end{array}$ & Expression of enzyme & $\begin{array}{l}\text { N. benthamiana infected with pSP } 6 \text { PepMoVVb1/EngD showed } \\
\text { increased senescence but milder symptoms than wild-type } \\
\text { PepMoV-Vb1. Glucose assay confirmed the EngD enzymatic } \\
\text { activity in infected plants and thus, suggested the use of a viral } \\
\text { vector for heterologous engD expression leading to the digestion } \\
\text { of cellulose substrate in plant cells for biomass production. }\end{array}$ & [93] \\
\hline
\end{tabular}


Table 4. Potential of potyviruses as expression vectors for the monitoring of viral infections in host plants.

\begin{tabular}{|c|c|c|c|}
\hline Virus & Genome Manipulation & Findings & Reference \\
\hline $\begin{array}{l}\text { Zucchini yellow mosaic } \\
\text { virus ZYMV }\end{array}$ & $\begin{array}{l}\text { Insertion of the } \triangle \text { SVBV-promoter ( } 328 \mathrm{bp} \\
\text { fragment) before the GUS reporter gene } \\
\text { replacing } 35 S \text { promoter in the binary p301, give } \\
\text { rise to } \triangle \text { SVBV-GUS-p301 }\end{array}$ & $\begin{array}{l}\triangle \text { SVBV-promoter [conserved CCACT (at -83) and TATA (at -31) } \\
\text { boxes] from Strawberry vein banding caulimovirus (SVBV) genome, } \\
\text { was identified as a novel putative promoter due to its ability in } \\
\text { driving infection of the full-length ZYMV cDNA. Stable expression } \\
\text { of GUS under the } \triangle \text { SVBV-promoter was shown in transformed } \\
\text { tobacco shoots in roots, leaves and stems. }\end{array}$ & {$[90]$} \\
\hline $\begin{array}{l}\text { Turnip mosaic virus } \\
\text { TuMV-UK1 }\end{array}$ & $\begin{array}{l}\text { p35Tunos/nGFP-cGUS and } \\
\text { p35Tunos/nGUS-cGFP contain reporter genes, } \\
\text { uidA and gfp inserted in between P1 and } \\
\text { HC-Pro/Pol and CP cistrons respectively, and } \\
\text { vice versa }\end{array}$ & $\begin{array}{l}\text { Attenuated systemic symptoms were observed in transfected } \\
\text { Brassica perviridis and Western blot analyses showed that both } \\
\text { foreign proteins were produced. GFP was stable over } 30 \mathrm{days} \\
\text { post-transfection (dpt) while uidA was gradually lost at } 15 \mathrm{dpt} \text { at } \\
\text { either sites. This indicate the possibility to produce two foreign } \\
\text { proteins simultaneously in a TuMV-based vector. }\end{array}$ & [86] \\
\hline Turnip mosaic virus TuMV & $\begin{array}{l}\text { Plasmids vec01-GUS and vec01-GFP contain } \\
\text { reporter genes, uidA and gfp inserted in } \\
\text { between NIb and } \mathrm{CP} \text { genes }\end{array}$ & $\begin{array}{l}\text { Both TuMV clones were infectious in Arabidopsis, with } \\
\text { characteristics (infectivity and symptomatology) similar to the } \\
\text { wild-type virus. }\end{array}$ & [12] \\
\hline $\begin{array}{l}\text { Tobacco vein banding } \\
\text { mosaic virus TVBMV HN39 }\end{array}$ & $\begin{array}{l}\text { pTVBMV-GFP contains an Aequoria victoriae } \\
\text { gfp gene inserted between the NIb and CP } \\
\text { encoding regions }\end{array}$ & $\begin{array}{l}\text { pTVBMV-GFP expressed stably in the systemically infected N. } \\
\text { benthamiana leaves, indicating suitability of pTVBMV as an } \\
\text { expression vector }\end{array}$ & [36] \\
\hline $\begin{array}{l}\text { Papaya ringspot virus } \\
\text { PRSV-Hainan }\end{array}$ & $\begin{array}{l}\text { PRSV-GFP contains a gfp gene between the NIb } \\
\text { and CP encoding regions }\end{array}$ & $\begin{array}{l}\text { PRSV-GFP transformed into Rhizobium radiobacter caused typical } \\
\text { symptoms and green fluorescence in inoculated papaya plants, } \\
\text { indicating that GFP can be expressed stably in PRSV vector without } \\
\text { affecting virus infection and movement. }\end{array}$ & [95] \\
\hline $\begin{array}{l}\text { Papaya ringspot virus } \\
\text { PRSV-W }\end{array}$ & $\begin{array}{l}\text { pCamPRSV-W-GFP contains a gfp gene inserted } \\
\text { into NIb- and CP-coding region }\end{array}$ & $\begin{array}{l}\text { Appearance of strong green fluorescence in systemic leaves of } \\
\text { agro-inoculated Cucurbita pepo, Cucumis melo, Citrullus lanatus } \\
\text { and Cucumis sativus plants indicated that pCamPRSV-W can } \\
\text { express foreign genes effectively. }\end{array}$ & [44] \\
\hline $\begin{array}{l}\text { Turnip mosaic virus } \\
\text { TuMV-YC5 }\end{array}$ & $\begin{array}{l}\text { In addition to the N-terminal (NT) of HC-Pro, } \\
\text { the NT regions of P3, CIP, NIb, and CP of } \\
\text { TuMV-YC } 5 \text { were engineered for a GFP/Der p } 5 \\
\text { ORF insertion }\end{array}$ & $\begin{array}{l}\text { In addition to the NT regions of HC-Pro and CP, the NT regions of } \\
\text { P3, CIP and NIb were also able to carry both heterologous ORFs to be } \\
\text { translated as a part of the polyprotein and processed as free-form } \\
\text { protein although showed more permissiveness to the GFP ORF than } \\
\text { Der p } 5 \text { ORF. The efficiency and stability of expression of the ORFs } \\
\text { depends on the particular ORF and the host plant employed. }\end{array}$ & [96] \\
\hline
\end{tabular}


Table 4. Cont.

\begin{tabular}{|c|c|c|c|}
\hline Virus & Genome Manipulation & Findings & Reference \\
\hline Tobacco etch virus TEV & $\begin{array}{l}\text { A series of six histidines (his-tag) inserted near } \\
\text { the } 5^{\prime} \text { terminus of the HC coding region in } \\
\text { pTEV-HCHXa }\end{array}$ & $\begin{array}{l}\text { pTEV-HCHXa was infectious, produced symptoms in tobacco } \\
\text { similarly as wild-type TEV, and stably maintained through at least } 4 \\
\text { cycles of aphid transmission. HC protein purification based on the } \\
\text { affinity of its his-tag for Ni2+-charged resin, yielded large amount of } \\
\text { fully functional his-tagged HC protein. }\end{array}$ & [97] \\
\hline $\begin{array}{l}\text { Clover yellow vein virus } \\
\text { CIYVV }\end{array}$ & $\begin{array}{l}\text { pCIYVV-GFP contains a gfp gene inserted } \\
\text { between P1 and HC-Pro. Junctions between the } \\
\text { inserted proteins contained the protease } \\
\text { cleavage recognition sites }\end{array}$ & $\begin{array}{l}\text { Green fluorescence was detected in broad bean, kidney bean, and } \\
\text { soybean plants infected with pClYVV-GFP. The stability of the } \\
\text { construct in the symptomatic tissues was confirmed by RT-PCR and } \\
\text { Western blot analyses. }\end{array}$ & [84] \\
\hline Plum pox virus PPV-D & $\begin{array}{l}\text { pICPPV-NK-GFP contains a gfp gene inserted } \\
\text { between the NIb and CP junction }\end{array}$ & $\begin{array}{l}\text { GFP was detected in crude extracts from PPV-NK-GFP infected } \\
\text { leaves by Western blot. Genetic stability of the chimera was } \\
\text { confirmed by IC-PCR amplification of a cDNA fragment including } \\
\text { the foreign sequence of expected size. Virus and GFP accumulations } \\
\text { were quantified in infected N. clevelandii plants by ELISA. }\end{array}$ & [88] \\
\hline $\begin{array}{l}\text { Soybean mosaic virus } \\
\text { SMV-G7H }\end{array}$ & $\begin{array}{l}\text { GFP cloned into pSMV-MCS between the P1 and } \\
\text { HC-Pro cistrons (pSMV-GFP) }\end{array}$ & $\begin{array}{l}\text { Typical mild mosaic symptoms and systemic expression of GFP } \\
\text { protein were detected in pSMV-GFP infected soybean. The GFP gene } \\
\text { was shown to be maintained stably in soybeans even after three } \\
\text { serial passages. }\end{array}$ & [87] \\
\hline Tobacco etch virus TEV & $\begin{array}{l}\text { pTEV7D contains a } \beta \text { glucuronidase (GUS) gene } \\
\text { between the polyprotein-coding sequences for } \\
\text { N-terminal 35-kDa proteinase and HC-Pro }\end{array}$ & $\begin{array}{l}\text { GUS act as a marker gene in TEV genome, demonstrating that virus } \\
\text { replication and movement can be monitored easily by using a simple } \\
\text { histochemical assay in situ. The GUS enzyme was proteolytically } \\
\text { excised as a fusion product with HC-Pro. }\end{array}$ & [91] \\
\hline Lettuce mosaic virus LMV-E & $\begin{array}{l}\text { pLMVE-GFP and pLMVE-GUS contains a } \\
\text { jellyfish GFP \& } \beta \text { glucuronidase (GUS) gene } \\
\text { respectively, fused to HC-Pro }\end{array}$ & $\begin{array}{l}\text { Both GFP- and GUS-tagged viruses induced attenuated symptoms in } \\
\text { susceptible lettuce cultivars Trocadero and Vanguard, compared to } \\
\text { wild-type. Accumulation of the recombinant viruses was either } \\
\text { undetectable (pLMVE-GUS) or strongly delayed and inhibited by } \\
90 \% \text { (pLMVE-GFP). In contrast to parental virus, the recombinants } \\
\text { were unable to overcome the resistance gene, mo12. }\end{array}$ & [83] \\
\hline $\begin{array}{l}\text { Pepper mottle virus } \\
\text { PepMoV-Vb1 }\end{array}$ & $\begin{array}{l}\text { SP6PepMoV-Vb1/GFP contains turboGFP } \\
\text { inserted between NIb and CP coding regions }\end{array}$ & $\begin{array}{l}\text { Expression of GFP was monitored under illumination. } \\
\text { SP6PepMoV-Vb1/GFP was highly infectious and symptoms were not } \\
\text { different from those induced by either pSP6PepMoV-Vb1/wild-type } \\
\text { PepMoV-Vb. }\end{array}$ & [98] \\
\hline
\end{tabular}


Table 4. Cont.

\begin{tabular}{|c|c|c|c|}
\hline Virus & Genome Manipulation & Findings & Reference \\
\hline $\begin{array}{l}\text { Papaya leaf distortion mosaic } \\
\text { virus PLDMV-DF }\end{array}$ & $\begin{array}{l}\text { pPLDMV-GFP and pPLDMV-mCherry contain a } \\
\text { GFP and } m \text { Cherry into the NIb/CP junction } \\
\text { respectively }\end{array}$ & $\begin{array}{l}\text { PLDMV-GFP or PLDMV-mCherry developed typical systemic } \\
\text { symptoms in } 95 \% \text { of infected papaya seedlings, in which } \\
\text { fluorescence was observed in leaves, stems, and roots. Both clones } \\
\text { were stable in papaya for more than } 90 \text { days and during six serial } \\
\text { passages at 30-day intervals. }\end{array}$ & [99] \\
\hline Pepper mottle virus PepMoV & $\begin{array}{l}\text { pPepMoV-I: GFP (with intron } 2 \text { of ST-LS1) } \\
\text { contains a gfp gene inserted between P1 and } \\
\text { HC-Pro }\end{array}$ & $\begin{array}{l}\text { The consistent enhancement of PepMoV RNA level and translation } \\
\text { products (GFP) observed in the study suggested a hypothesis that } \\
\text { the intron ST-LS1 enhanced the stability and translational efficiency } \\
\text { of the PepMoV transcripts in the infiltrated leaves. }\end{array}$ & [100] \\
\hline Plum pox virus PPV-NAT & $\begin{array}{l}\text { pPPV-H6K1-NAT contains a histidine tag } \\
\text { inserted in the protein of a } 6 \mathrm{kDa}(6 \mathrm{~K} 1) \text { coding } \\
\text { region }\end{array}$ & $\begin{array}{l}\text { For detection of } 6 \mathrm{~K} 1 \text { as a mature protein of } 6 \mathrm{kDa} \text { in vivo, } \\
\text { pPPV-H6K1-NAT enabled the concentration and purification of } \\
\text { histidine-tagged } 6 \mathrm{~K} 1 \text { from infected Nicotiana benthamiana leaves at } 4 \text {, } \\
7 \text { and } 14 \text { days post-inoculation (d.p.i.) through affinity } \\
\text { chromatography. }\end{array}$ & [101] \\
\hline Plum pox virus PPV-Rec & $\begin{array}{l}\text { pIC-PPV-Rec-P1His contains a sequence coding } \\
\text { for six histidine residues inserted between the } \\
4 \text { th and } 5 \text { th amino acid of the P1 protein }\end{array}$ & $\begin{array}{l}\text { The pIC-PPV-Rec-P1His was able to replicate in N. benthamiana and } \\
\text { remained stable during several mechanical passages of the virus. } \\
\text { Immunoblot analysis with the anti-his antibody showed a diffuse } \\
\text { band corresponding to the molecular weight about } 70-80 \mathrm{kDa} \text { in the } \\
\text { root samples from early stage of infection. However, this signal } \\
\text { culminated on the sixth day post inoculation, later it rapidly } \\
\text { disappeared. }\end{array}$ & [102] \\
\hline Potato virus Y PVY-RB & $\begin{array}{l}\text { pGPVY-Ros1 contains a Antirrhinum majus } \\
\text { Rosea1 transcription factor inserted between the } \\
\text { NIb and CP cistrons }\end{array}$ & $\begin{array}{l}\text { - Mechanically inoculated solanaceous plants induced the } \\
\text { formation of red infection foci in inoculated tissue and solid } \\
\text { dark red pigmentation in systemically infected tissue, which } \\
\text { allows disease progression to be easily monitored } \\
\text { - Facilitated the novel quantitative analysis of antiviral activity in } \\
\text { plants by using silver nanoparticles, a nanomaterial with } \\
\text { exciting antimicrobial properties } \\
\text { Enabled the visual monitoring the virus transmission by an } \\
\text { aphid vector }\end{array}$ & [94] \\
\hline
\end{tabular}




\section{Conclusions}

Reverse genetics in virology relies on cDNA intermediates in order to genetically manipulate RNA viruses and further produce biologically active RNA molecules. Likewise, the available infectious full-length cDNA clones of potyviruses enable countless reverse genetics studies on phenotypic alteration and cross-protection by mutated viruses as well as in determining viral elements responsible for a particular biological characteristic of the virus. Apart from improving our understanding on the complexities of interactions between host and viral factors, reverse genetics strategies have also made various applications of recombinant vectors possible. Furthermore, the approach contributed immeasurably to the elucidation of basic functions of potyviral proteins, certain motifs or genome sequences in viral replication, transmission, and cell-to-cell movement. All these findings, in conjunction with different approaches such as transciptomics and proteomics analyses, would lead to the building of a larger network that helps to further explore potyviruses, especially in the identification of more durable resistance genes. Hence, reverse genetics technologies of potyviruses are believed to hold great promise for commercial applications in the future. Despite these breakthroughs, although various viral determinants have been identified through plant-potyvirus pathosystems, the host targets of those determinants are yet to be characterized in the future.

Author Contributions: Conceptualization, H.B.; resources, M.K. and H.B.; writing—original draft preparation, M.K.; writing-review and editing, M.K., Z.Z., I.I., S.N.B., and H.B.; funding acquisition, H.B. and Z.Z. All authors have read and agreed to the published version of the manuscript.

Funding: This research was funded by Ministry of Higher Education Malaysia grant number FRGS/1/2019/ STG05/UKM/02/2.

Conflicts of Interest: The authors declare no conflict of interest.

\section{References}

1. Aubry, F.; Nougairede, A.; Gould, E.A.; de Lamballerie, X. Flavivirus reverse genetic systems, construction techniques and applications: A historical perspective. Antiviral Res. 2015, 114, 67-85. [CrossRef]

2. Jackson, A.O.; Li, Z. Developments in plant negative-strand RNA virus reverse genetics. Annu. Rev. Phytopathol. 2016, 54, 469-498. [CrossRef]

3. Tomlinson, K.R.; Pablo-Rodriguez, J.L.; Bunawan, H.; Nanyiti, S.; Green, P.; Miller, J.; Alicai, T.; Seal, S.E.; Bailey, A.M.; Foster, G.D. Cassava brown streak virus Ham1 protein hydrolyses mutagenic nucleotides and is a necrosis determinant. Mol. Plant Pathol. 2019, 20, 1080-1092. [CrossRef]

4. Yang, C.C.; Hu, H.S.; Wu, R.H.; Wu, S.H.; Lee, S.J.; Jiaang, W.T.; Chern, J.H.; Huang, Z.S.; Wu, H.N.; Chang, C.M.; et al. A novel dengue virus inhibitor, BP13944, discovered by high-throughput screening with dengue virus replicon cells selects for resistance in the viral NS2B/NS3 protease. Antimicrob. Agents Chemother. 2014, 58, 110-119. [CrossRef] [PubMed]

5. Chambers, T.J.; Nestorowicz, A.; Mason, P.W.; Rice, C.M. Yellow fever/Japanese encephalitis chimeric viruses: Construction and biological properties. J. Virol. 1999, 73, 3095-3101. [CrossRef]

6. Youssef, F.; Marais, A.; Faure, C.; Gentit, P.; Candresse, T. Strategies to facilitate the development of uncloned or cloned infectious full-length viral cDNAs: Apple chlorotic leaf spot virus as a case study. Virol. J. 2011, 8, 488. [CrossRef] [PubMed]

7. Racaniello, V.R.; Baltimore, D. Cloned poliovirus complementary DNA is infectious in mammalian cells. Science (80-. ) 1981, 214, 916-919. [CrossRef] [PubMed]

8. Peeters, B.; de Leeuw, O. A single-plasmid reverse genetics system for the rescue of non-segmented negative-strand RNA viruses from cloned full-length cDNA. J. Virol. Methods 2017, 248, 187-190. [CrossRef]

9. The Online (10th) Report of the International Committee on Taxonomy of Viruses: 2018b Release. Available online: https://talk.ictvonline.org/ictv-reports/ictv_online_report/positive-sense-rna-viruses/w/potyviridae/ 572/genus-potyvirus (accessed on 12 December 2019).

10. Wylie, S.J.; Adams, M.; Chalam, C.; Kreuze, J.; López-Moya, J.J.; Ohshima, K.; Praveen, S.; Rabenstein, F.; Stenger, D.; Wang, A.; et al. ICTV Virus Taxonomy Profile: Potyviridae. J. Gen. Virol. 2017, 98, 352-354. [CrossRef] 
11. Dolja, V.V.; Herndon, K.L.; Pirone, T.P.; Carrington, J.C. Spontaneous Mutagenesis of a Plant Potyvirus Genome after Insertion of a Foreign Gene. J. Virol. 1993, 67, 5968-5975. [CrossRef]

12. Tourino, A.; Sanchez, F.; Castiel, A.F.; Ponz, F. High expression of foreign proteins from a biosafe viral vector derived from Turnip mosaic virus. Spanish J. Agric. Res. 2008, 6, 48-58. [CrossRef]

13. Saenz, P.; Cervera, M.T.; Dallot, S.; Quiot, L.; Quiot, J.B.; Riechmann, J.L.; Garcia, J.A. Identification of a pathogenicity determinant of Plum pox virus in the sequence encoding the C-terminal region of protein $\mathrm{P} 3+$ 6K1. J. Gen. Virol. 2000, 81, 557-566. [CrossRef]

14. Hollings, M.; Brunt, A.A. Potyviruses. In Handbook of plant virus infection: Comparative diagnosis; Elsevier Science Ltd.: Amsterdam, The Netherlands, 1981.

15. Riechmann, J.L.; Lain, S.; Garcia, J.A. Highlights and prospects of potyvirus molecular biology. J. Gen. Virol. 1992, 73, 1-16. [CrossRef]

16. Urcuqui-Inchima, S.; Haenni, A.L.; Bernardi, F. Potyvirus proteins: A wealth of functions. Virus Res. 2001, 74, 157-175. [CrossRef]

17. Kondo, T.; Fujita, T. Complete nucleotide sequence and construction of an infectious clone of Chinese yam necrotic mosaic virus suggest that macluraviruses have the smallest genome among members of the family Potyviridae. Arch. Virol. 2012, 157, 2299-2307. [CrossRef]

18. Yusop, M.S.M.; Saad, M.F.M.; Talip, N.; Baharum, S.N.; Bunawan, H. A Review on Viruses Infecting Taro (Colocasia esculenta (L.) Schott). Pathogens 2019, 8, 56. [CrossRef]

19. Chung, B.Y.W.; Miller, W.A.; Atkins, J.F.; Firth, A.E. An overlapping essential gene in the Potyviridae. Proc. Natl. Acad. Sci. USA 2008, 105, 5897-5902. [CrossRef]

20. Kannan, M.; Ismail, I.; Bunawan, H. Maize dwarf mosaic virus: From genome to disease management. Viruses 2018, 10, 492. [CrossRef]

21. Ahlquist, P.; Janda, M. cDNA Cloning and In Vitro Transcription of the Complete Brome Mosaic Virus Genome. Mol. Cell. Biol. 1984, 4, 2876-2882. [CrossRef]

22. Lin, Y.Y.; Fang, M.M.; Lin, P.C.; Chiu, M.T.; Liu, L.Y.; Lin, C.P.; Lin, S.S. Improving initial infectivity of the Turnip mosaic virus (TuMV) infectious clone by an mini binary vector via agro-infiltration. Bot. Stud. 2013, 54, 22. [CrossRef]

23. Duff-Farrier, C.R.A.; Mbanzibwa, D.R.; Nanyiti, S.; Bunawan, H.; Pablo-Rodriguez, J.L.; Tomlinson, K.R.; James, A.M.; Alicai, T.; Seal, S.E.; Bailey, A.M.; et al. Strategies for the construction of cassava brown streak disease viral infectious clones. Mol. Biotechnol. 2019, 61, 93-101. [CrossRef]

24. Lopez-Moya, J.J.; Garcia, J.A. Construction of a stable and highly infectious intron-containing cDNA clone of plum pox potyvirus and its use to infect plants by particle bombardment. Virus Res. 2000, 68, 99-107. [CrossRef]

25. Junqueira, B.R.T.; Nicolini, C.; Lucinda, N.; Orílio, A.F.; Nagata, T. A simplified approach to construct infectious cDNA clones of a tobamovirus in a binary vector. J. Virol. Methods 2014, 198, 32-36. [CrossRef]

26. Point Mutation. Available online: https://www.britannica.com/science/point-mutation (accessed on 11 July 2020).

27. Daubert, S. Sequence determinants of symptoms in the genomes of plant viruses, viroids, and satellites. Mol. Plant-Microbe Interact 1988, 1, 317-325. [CrossRef]

28. Andrejeva, J.; Puurand, U.; Merits, A.; Rabenstein, F.; Valkonen, J.P. Potyvirus helper component-proteinase and coat protein $(\mathrm{CP})$ have coordinated functions in virus-host interactions and the same $\mathrm{CP}$ motif affects virus transmission and accumulation. J. Gen. Virol. 1999, 80, 1133-1139. [CrossRef] [PubMed]

29. Tacahashi, Y.; Uyeda, I. Restoration of the $3^{\prime}$ end of potyvirus RNA derived from poly (A)-deficient infectious cDNA clones. Virology 1999, 152, 147-152. [CrossRef] [PubMed]

30. Simon-Buela, L.; Guo, H.S.; Garcia, J.A. Long sequences in the 5' noncoding region of plum pox virus are not necessary for viral infectivity but contribute to viral competitiveness and pathogenesis. Virology 1997, 233, 157-162. [CrossRef] [PubMed]

31. Rodriguez-Cerezo, E.; Klein, P.G.; Shaw, J.G. A determinant of disease symptom severity is located in the 3'-terminal noncoding region of the RNA of a plant virus. Proc. Natl. Acad. Sci. USA 1991, 88, 9863-9867. [CrossRef] [PubMed]

32. Atreya, C.D.; Atreya, P.L.; Thornbury, D.W.; Pirone, T.P. Site-directed mutations in the potyvirus HC-Pro gene affect helper component activity, virus accumulation, and symptom expression in infected tobacco plants. Virology 1992, 191, 106-111. [CrossRef] 
33. Sekiguchi, H.; Tacahashi, Y.; Uyeda, I. The $3^{\prime}$ terminal region is strictly required for clover yellow vein virus genome replication. Arch. Virol. 2003, 148, 759-772. [CrossRef]

34. Ivanov, K.I.; Puustinen, P.; Gabrenaite, R.; Vihinen, H.; Ronnstrand, L.; Valmu, L.; Kalkkinen, N.; Makinen, K. Phosphorylation of the potyvirus capsid protein by protein kinase CK2 and its relevance for virus infection. Plant Cell 2003, 15, 2124-2139. [CrossRef] [PubMed]

35. Moury, B.; Simon, V. dN/dS-based methods detect positive selection linked to trade-offs between different fitness traits in the coat protein of potato virus Y. Mol. Biol. Evol. 2011, 28, 2707-2717. [CrossRef] [PubMed]

36. Gao, R.; Tian, Y.P.; Wang, J.; Yin, X.; Li, X.D.; Valkonen, J.P. Construction of an infectious cDNA clone and gene expression vector of Tobacco vein banding mosaic virus (genus Potyvirus). Virus Res. 2012, 169, $276-281$. [CrossRef] [PubMed]

37. Hajimorad, M.R.; Eggenberger, A.L.; Hill, J.H. Evolution of Soybean mosaic virus-G7 molecularly cloned genome in Rsv1-genotype soybean results in emergence of a mutant capable of evading Rsv1-mediated recognition. Virology 2003, 314, 497-509. [CrossRef]

38. Li, M.J.; Kim, J.K.; Seo, E.Y.; Hong, S.M.; Hwang, E.I.; Moon, J.K.; Domier, L.L.; Hammond, J.; Youn, Y.N.; Lim, H.S. Sequence variability in the HC-Pro coding regions of Korean soybean mosaic virus isolates is associated with differences in RNA silencing suppression. Arch. Virol. 2014, 159, 1373-1383. [CrossRef]

39. Yap, Y.K.; Duangjit, J.; Panyim, S. N-terminal of Papaya ringspot virus type-W (PRSV-W) helper component proteinase (HC-Pro) is essential for PRSV systemic infection in zucchini. Virus Genes 2009, 38, 461-467. [CrossRef]

40. McKinney, H. Mosaic diseases in the Canary Islands, West Africa and Gibraltar. J. Agric. Res. 1929, 39, 577-578.

41. Nakazono-Nagaoka, E.; Takahashi, T.; Shimizu, T.; Kosaka, Y.; Natsuaki, T.; Omura, T.; Sasaya, T. Cross-protection against Bean yellow mosaic virus (BYMV) and Clover yellow vein virus by attenuated BYMV isolate M11. Phytopathology 2009, 99, 251-257. [CrossRef]

42. Lin, S.S.; Wu, H.W.; Jan, F.J.; Hou, R.F.; Yeh, S.D. Modifications of the helper component-protease of Zucchini yellow mosaic virus for generation of attenuated mutants for cross protection against severe infection. Phytopathology 2007, 97, 287-296. [CrossRef]

43. Pasin, F.; Menzel, W.; Daros, J.A. Harnessed viruses in the age of metagenomics and synthetic biology: An update on infectious clone assembly and biotechnologies of plant viruses. Plant Biotechnol. J. 2019, 17, 1010-1026. [CrossRef]

44. Huang, X.D.; Fang, L.; Gu, Q.S.; Tian, Y.P.; Geng, C.; Li, X.D. Cross protection against the watermelon strain of Papaya ringspot virus through modification of viral RNA silencing suppressor. Virus Res. 2019, 265, 166-171. [CrossRef] [PubMed]

45. Gal-On, A. A point mutation in the FRNK motif of the potyvirus helper component-protease gene alters symptom expression in cucurbits and elicits protection against the severe homologous virus. Phytopathology 2000, 90, 467-473. [CrossRef]

46. Nagyova, A.; Subr, Z. Infectious full-length clones of plant viruses and their use for construction of viral vectors. Acta Virol. 2007, 51, 223-237.

47. Sardaru, P.; Sinausia, L.; Lopez-Gonzalez, S.; Zindovic, J.; Sanchez, F.; Ponz, F. The apparent non-host resistance of Ethiopian mustard to a radish-infecting strain of Turnip mosaic virus is largely determined by the C-terminal region of the P3 viral protein. Mol. Plant Pathol. 2018, 19, 1984-1994. [CrossRef]

48. Janzac, B.; Montarry, J.; Palloix, A.; Navaud, O.; Moury, B. A point mutation in the polymerase of Potato virus $\mathrm{Y}$ confers virulence toward the Pvr4 resistance of pepper and a high competitiveness cost in susceptible cultivar. Mol. plant-microbe Interact. 2010, 23, 823-830. [CrossRef]

49. Johansen, I.E.; Dougherty, W.G.; Keller, K.E.; Wang, D.; Hampton, R.O. Multiple viral determinants affect seed transmission of pea seedborne mosaic virus in Pisum sativum. J. Gen. Virol. 1996, 77, 3149-3154. [CrossRef]

50. Chu, M.; Lopez-Moya, J.J.; Llave-Correas, C.; Pirone, T.P. Two separate regions in the genome of the tobacco etch virus contain determinants of the wilting response of Tabasco pepper. Mol. Plant-Microbe Interact. 1997, 10, 472-480. [CrossRef]

51. Bukovinszki, A.; Gotz, R.; Johansen, E.; Maiss, E.; Balazs, E. The role of the coat protein region in symptom formation on Physalis floridana varies between PVY strains. Virus Res. 2007, 127, 122-125. [CrossRef] 
52. Tribodet, M.; Glais, L.; Kerlan, C.; Jacquot, E. Characterization of Potato virus Y (PVY) molecular determinants involved in the vein necrosis symptom induced by PVYN isolates in infected Nicotiana tabacum cv. Xanthi. J. Gen. Virol. 2005, 86, 2101-2105. [CrossRef]

53. Faurez, F.; Baldwin, T.; Tribodet, M.; Jacquot, E. Identification of new Potato virus Y (PVY) molecular determinants for the induction of vein necrosis in tobacco. Mol. Plant Pathol. 2012, 13, 948-959. [CrossRef]

54. Andersen, K.; Johansen, I.E. A Single Conserved Amino Acid in the Coat Protein Gene of Pea Seed-Borne Mosaic Potyvirus Modulates the Ability of the Virus to Move Systemically inChenopodium quinoa. Virology 1998, 241, 304-311. [CrossRef]

55. Jenner, C.E.; Sanchez, F.; Nettleship, S.B.; Foster, G.D.; Ponz, F.; Walsh, J.A. The cylindrical inclusion gene of Turnip mosaic virus encodes a pathogenic determinant to the Brassica resistance gene TuRB01. Mol. Plant-Microbe Interact. 2000, 13, 1102-1108. [CrossRef]

56. Redondo, E.; Krause-Sakate, R.; Yang, S.J.; Lot, H.; Le Gall, O.; Candresse, T. Lettuce mosaic virus pathogenicity determinants in susceptible and tolerant lettuce cultivars map to different regions of the viral genome. Mol. Plant-Microbe Interact. 2001, 14, 804-810. [CrossRef]

57. Jenner, C.E.; Tomimura, K.; Ohshima, K.; Hughes, S.L.; Walsh, J.A. Mutations in Turnip mosaic virus P3 and cylindrical inclusion proteins are separately required to overcome two Brassica napus resistance genes. Virology 2002, 300, 50-59. [CrossRef]

58. Keller, K.E.; Johansen, E.; Martin, R.R.; Hampton, R.O. Potyvirus genome-linked protein (VPg) determines pea seed-borne mosaic virus pathotype-specific virulence in Pisum sativum. Mol. Plant-Microbe Interact. 1998, 11, 124-130. [CrossRef]

59. Moury, B.; Morel, C.; Johansen, E.; Guilbaud, L.; Souche, S.; Ayme, V.; Caranta, C.; Palloix, A.; Jacquemond, M. Mutations in Potato virus $\mathrm{Y}$ genome-linked protein determine virulence toward recessive resistances in Capsicum annuum and Lycopersicon hirsutum. Mol. Plant-Microbe Interact. 2004, 17, 322-329. [CrossRef]

60. Ayme, V.; Petit-Pierre, J.; Souche, S.; Palloix, A.; Moury, B. Molecular dissection of the potato virus Y VPg virulence factor reveals complex adaptations to the pvr2 resistance allelic series in pepper. J. Gen. Virol. 2007, 88, 1594-1601. [CrossRef]

61. Jenner, C.E.; Wang, X.; Tomimura, K.; Ohshima, K.; Ponz, F.; Walsh, J.A. The dual role of the potyvirus P3 protein of Turnip mosaic virus as a symptom and avirulence determinant in brassicas. Mol. Plant-Microbe Interact. 2003, 16, 777-784. [CrossRef]

62. Lopez-Gonzalez, S.; Aragones, V.; Daros, J.A.; Sanchez, F.; Ponz, F. An infectious cDNA clone of a radish-infecting Turnip mosaic virus strain. Eur. J. Plant Pathol. 2017, 148, 207-211. [CrossRef]

63. Suehiro, N.; Natsuaki, T.; Watanabe, T.; Okuda, S. An important determinant of the ability of Turnip mosaic virus to infect Brassica spp. and / or Raphanus sativus is in its P3 protein Printed in Great Britain. J. Gen. Virol. 2004, 85, 2087-2098. [CrossRef]

64. Kim, K.S.; Oh, H.Y.; Suranto, S.; Nurhayati, E.; Gough, K.H.; Shukla, D.D.; Pallaghy, C.K. Infectivity of in vitro transcripts of Johnsongrass mosaic potyvirus full-length cDNA clones in maize and sorghum. Arch. Virol. 2003, 148, 563-574. [CrossRef]

65. Azad, A.K.; Amin, L.; Sidik, N.M. Gene technology for papaya ringspot virus disease management. Sci. World J. 2014, 1-11. [CrossRef]

66. Chen, K.C.; Chiang, C.H.; Raja, J.A.; Liu, F.L.; Tai, C.H.; Yeh, S.D. A single amino acid of NIaPro of Papaya ringspot virus determines host specificity for infection of papaya. Mol. Plant-Microbe Interact. 2008, 21, 1046-1057. [CrossRef]

67. Chen, K.C.; Yeh, S.D. Genetic Determinant of Papaya Ringspot Virus for Infection of Papaya. Acta Hortic. 2010, 163-172. [CrossRef]

68. Naderpour, M.; Johansen, I.E. Visualization of resistance responses in Phaseolus vulgaris using reporter tagged clones of Bean common mosaic virus. Virus Res. 2011, 159, 1-8. [CrossRef]

69. Larsen, R.C.; Miklas, P.N.; Druffel, K.L.; Wyatt, S.D. NL-3 K strain is a stable and naturally occurring interspecific recombinant derived from Bean common mosaic necrosis virus and Bean common mosaic virus. Phytopathology 2005, 95, 1037-1042. [CrossRef]

70. Grumet, R.; Ullah, Z.; Gal-On, A.; Raccah, B. Cucurbit-potyvirus interactions influencing virus movement and accumulation. VII Eucarpia Meet. Cucurbit Genet. Breed. 2000, 510, 327-334. [CrossRef]

71. Grangeon, R.; Agbeci, M.; Chen, J.; Grondin, G.; Zheng, H.; Laliberte, J.F. Impact on the endoplasmic reticulum and Golgi apparatus of turnip mosaic virus infection. J. Virol. 2012, 86, 9255-9265. [CrossRef] 
72. Rodrigo, G.; Martinez, F.; Aragones, V.; Ruiz, M.; Lodewijk, I.; Fernandez, U.; Elena, S.F.; Daros Arnau, J.A. Interaction network of tobacco etch potyvirus NIa protein with the host proteome during infection. BMC Genomics 2016, 17, 87. [CrossRef]

73. Merits, A.; Rajamäki, M.L.; Lindholm, P.; Runeberg-Roos, P.; Kekarainen, T.; Puustinen, P.; Mäkeläinen, K.; Valkonen, J.P.; Saarma, M. Proteolytic processing of potyviral proteins and polyprotein processing intermediates in insect and plant cells. J. Gen. Virol. 2002, 83, 1211-1221. [CrossRef]

74. Elena, S.F.; Rodrigo, G. Towards an integrated molecular model of plant-virus interactions. Curr. Opin. Virol. 2012, 2, 719-724. [CrossRef] [PubMed]

75. Zheng, H.; Yan, F.; Lu, Y.; Sun, L.; Lin, L.; Cai, L.; Hou, M.; Chen, J. Mapping the self-interacting domains of TuMV HC-Pro and the subcellular localization of the protein. Virus Genes 2011, 42, 110-116. [CrossRef] [PubMed]

76. Revers, F.; García, J.A. Molecular biology of potyviruses. Adv. Virus Res. 2015, 92, 101-199. [CrossRef] [PubMed]

77. Desbiez, C.; Girard, M.; Lecoq, H. A novel natural mutation in HC-Pro responsible for mild symptomatology of Zucchini yellow mosaic virus (ZYMV, Potyvirus) in cucurbits. Arch. Virol. 2010, 155, 397-401. [CrossRef]

78. Seo, J.K.; Kang, S.H.; Seo, B.Y.; Jung, J.K.; Kim, K.H. Mutational analysis of interaction between coat protein and helper component-proteinase of Soybean mosaic virus involved in aphid transmission. Mol. Plant Pathol. 2010, 11, 265-276. [CrossRef]

79. Wang, Y.; Yang, Z.Y.; Tian, Y.P.; Geng, C.; Yuan, X.F.; Li, X.D. Role of Tobacco vein banding mosaic virus 3'-UTR on virus systemic infection in tobacco. Virology 2019, 527, 38-46. [CrossRef]

80. Bryan, G.T.; Gardner, R.C.; Forster, R.L.S. Nucleotide sequence of the coat protein gene of a strain of clover yellow vein virus from New Zealand: Conservation of a stem-loop structure in the $3^{\prime}$ region of potyviruses. Arch. Virol. 1992, 124, 133-146. [CrossRef]

81. Chen, T.C.; Hsu, H.T.; Jain, R.K.; Huang, C.W.; Lin, C.H.; Liu, F.L.; Yeh, S.D. Purification and serological analyses of tospoviral nucleocapsid proteins expressed by Zucchini yellow mosaic virus vector in squash. J. Virol. Methods 2005, 129, 113-124. [CrossRef]

82. Guo, H.S.; Lopez-Moya, J.J.; Garcia, J.A. Susceptibility to recombination rearrangements of a chimeric plum pox potyvirus genome after insertion of a foreign gene. Virus Res. 1998, 57, 183-195. [CrossRef]

83. German-Retana, S.; Candresse, T.; Alias, E.; Delbos, R.P.; Le Gall, O. Effects of green fluorescent protein or $\beta$-glucuronidase tagging on the accumulation and pathogenicity of a resistance-breaking Lettuce mosaic virus isolate in susceptible and resistant lettuce cultivars. Mol. Plant-Microbe Interact. 2000, 13, 316-324. [CrossRef]

84. Masuta, C.; Yamana, T.; Tacahashi, Y.; Uyeda, I.; Sato, M.; Ueda, S.; Matsumura, T. Development of clover yellow vein virus as an efficient, stable gene-expression system for legume species. Plant J. 2000, 23, 539-546. [CrossRef]

85. Johansen, I.E.; Lund, O.S.; Hjulsager, C.K.; Laursen, J. Recessive resistance in Pisum sativum and potyvirus pathotype resolved in a gene-for-cistron correspondence between host and virus. J. Virol. 2001, 75, 6609-6614. [CrossRef]

86. Beauchemin, C.; Bougie, V.; Laliberté, J.F. Simultaneous production of two foreign proteins from a potyvirus-based vector. Virus Res. 2005, 112, 1-8. [CrossRef]

87. Seo, J.K.; Lee, H.G.; Kim, K.H. Systemic gene delivery into soybean by simple rub-inoculation with plasmid DNA of a Soybean mosaic virus-based vector. Arch. Virol. 2009, 154, 87. [CrossRef]

88. Fernandez-Fernandez, M.R.; Mourino, M.; Rivera, J.; Rodriguez, F.; Plana-Durán, J.; Garcia, J.A. Protection of rabbits against rabbit hemorrhagic disease virus by immunization with the VP60 protein expressed in plants with a potyvirus-based vector. Virology 2001, 280, 283-291. [CrossRef]

89. Rajamaki, M.L.; Maki-Valkama, T.; Makinen, K.; Valkonen, J.P. Infection with Potyviruses. In Plant-Pathogen Interactions; Blackwell: Oxford, UK, 2004; ISBN 1-4051-1433-9.

90. Wang, Y.; Gaba, V.; Wolf, D.; Xia, X.D.; Gal-On, A. Identification of a novel plant virus promoter using a potyvirus infectious clone. Virus Genes 2000, 20,11-17. [CrossRef]

91. Dolja, V.V.; McBride, H.J.; Carrington, J.C. Tagging of plant potyvirus replication and movement by insertion of beta-glucuronidase into the viral polyprotein. Proc. Natl. Acad. Sci. USA 1992, 89, 10208-10212. [CrossRef] [PubMed] 
92. French, R.; Janda, M.; Ahlquist, P. Bacterial gene inserted in an engineered RNA virus: Efficient expression in monocotyledonous plant cells. Science (80-. ) 1986, 231, 1294-1297. [CrossRef]

93. Song, E.; Ryu, K. A pepper mottle virus - based vector enables systemic expression of endoglucanase D in non-transgenic plants. Arch. Virol. 2017, 162, 3717-3726. [CrossRef]

94. Cordero, T.; Mohamed, M.A.; Lopez-Moya, J.J.; Daros, J.A. A recombinant potato virus y infectious clone tagged with the rosea1 visual marker (pvy-ros1) facilitates the analysis of viral infectivity and allows the production of large amounts of anthocyanins in plants. Front. Microbiol. 2017, 8, 611. [CrossRef]

95. Tuo, D.; Fu, L.; Shen, W.; Li, X.; Zhou, P.; Yan, P. Generation of stable infectious clones of plant viruses by using Rhizobium radiobacter for both cloning and inoculation. Virology 2017, 510, 99-103. [CrossRef] [PubMed]

96. Chen, C.; Chen, T.; Raja, J.A.J.; Chang, C.; Chen, L.; Lin, S.; Yeh, S. Effectiveness and stability of heterologous proteins expressed in plants by Turnip mosaic virus vector at five different insertion sites. Virus Res. 2007, 130, 210-227. [CrossRef] [PubMed]

97. Blanc, S.; Dolja, V.V.; Llave, C.; Pirone, T.P. Histidine-tagging and purification of tobacco etch potyvirus helper component protein. J. Virol. Methods 1999, 77, 11-15. [CrossRef]

98. Lee, M.Y.; Song, Y.S.; Ryu, K.H. Development of infectious transcripts from full-length and GFP-tagged cDNA clones of Pepper mottle virus and stable systemic expression of GFP in tobacco and pepper. Virus Res. 2011, 155, 487-494. [CrossRef] [PubMed]

99. Tuo, D.C.; Yan, P.; Zhao, G.Y.; Li, X.Y.; Zhou, P.; Shen, W.T. Two agroinfection-compatible fluorescent protein-tagged infectious cDNA clones of papaya leaf distortion mosaic virus facilitate the tracking of virus infection. Acta Virol. 2018, 202-207. [CrossRef]

100. Tran, A.P.; Miao, F.; Widyasari, K.; Kim, K. A plant intron enhances the performance of an infectious clone in planta. J. Virol. Methods 2018. [CrossRef]

101. Waltermann, A.; Maiss, E. Detection of $6 \mathrm{~K} 1$ as a mature protein of $6 \mathrm{kDa}$ in plum pox virus-infected Nicotiana benthamiana. J. Gen. Virol. 2006, 87, 2381-2386. [CrossRef]

102. Vozarova, Z.; Glasa, M.; Subr, Z.W. Tracking the potyviral P1 protein in Nicotiana benthamiana plants during plum pox virus infection. Acta Virol. 2017, 61, 492-494. [CrossRef]

103. Libsittikul, S.; Khongwichit, S.; Smith, D.R.; Yap, Y.K. Evaluation of papaya ringspot virus as a vector for expression of dengue E protein domain III in Cucurbita pepo (Zucchini) plants. J. Anim. Plant Sci. 2015, 25, 809-815.

104. Kelloniemi, J.; Makinen, K.; Valkonen, J.P. A potyvirus-based gene vector allows producing active human S-COMT and animal GFP, but not human sorcin, in vector-infected plants. Biochimie 2006, 88, 505-513. [CrossRef]

105. Arazi, T.; Slutsky, S.G.; Shiboleth, Y.M.; Wang, Y.; Rubinstein, M.; Barak, S.; Yang, J.; Gal-On, A. Engineering zucchini yellow mosaic potyvirus as a non-pathogenic vector for expression of heterologous proteins in cucurbits. J. Biotechnol. 2001, 87, 67-82. [CrossRef]

106. Hsu, C.H.; Lin, S.S.; Liu, F.L.; Su, W.C.; Yeh, S.D. Oral administration of a mite allergen expressed by zucchini yellow mosaic virus in cucurbit species downregulates allergen-induced airway inflammation and $\operatorname{IgE}$ synthesis. J. Allergy Clin. Immunol. 2004, 113, 1079-1085. [CrossRef] [PubMed]

(C) 2020 by the authors. Licensee MDPI, Basel, Switzerland. This article is an open access article distributed under the terms and conditions of the Creative Commons Attribution (CC BY) license (http://creativecommons.org/licenses/by/4.0/). 